Landscape scenarios and implications for streamflow in New England

Co-designed land-use scenarios and their implications for storm runoff and streamflow in

New England

\author{
Andrew J. GUSWA, ${ }^{1, *}$ \\ Brian HALL ${ }^{2}$ \\ Chingwen $\mathrm{CHENG}^{3}$ \\ Jonathan R. THOMPSON ${ }^{4}$ \\ * Corresponding author
}

111 Picker Engineering Program, 100 Green Street, Smith College, Northampton, Massachusetts

12 01063, 1-413-585-7019, aguswa@smith.edu

132 Harvard Forest, Harvard University, Petersham, MA 01366, brhall@fas.harvard.edu

143 The Design School, Arizona State University, Tempe, AZ 85287, Chingwen.Cheng@asu.edu

4 Harvard Forest, Harvard University, Petersham, MA 01366, jthomps@,fas.harvard.edu

Keywords: land-use change; ecosystem services; storm runoff; streamflow; landscape scenarios; New England

\title{
Research highlights
}

1. Stakeholder-engaged scenarios provide meaningful and plausible futures for the New England landscape and assessment of effects of land-use change on storm runoff and streamflow

2. Effects of land use on the overall water balance are small across the landscape scenarios

3. Future land-use change has the potential to affect storm runoff and high flows to a degree that is comparable to the effects due to changes in climate in 2060

4. The degree of natural resource innovation affects storm runoff and high flows when 
Landscape scenarios and implications for streamflow in New England

\section{Abstract}

39 Future changes in both landscape and climate have the potential to create or exacerbate problems

40 with stormwater management, high flows, and flooding. In New England, four plausible land-

41 use scenarios were co-developed with stakeholders to give insight to the effects on ecosystem

42 services of different trajectories of socio-economic connectedness and natural resource

43 innovation. To assess the effects of these land-use scenarios on water-related ecosystem

44 services, we applied the Soil and Water Assessment Tool to two watersheds under two climates.

45 Differences in land use had minimal effects on the overall water balance but did affect high

46 flows and the relative contribution of storm runoff to streamflow. For most of the scenarios, the

47 effect was small and less than the effect due to climate change. For one scenario - envisioned to

48 have global socio-economic connectedness and low levels of natural-resource innovation - the

49 effects of land-use changes were comparable to the effects due to climate. For that scenario,

50 changes to the landscape increased the annual maximum daily flow by $10 \%$, similar to the $5-15 \%$

51 increase attributable to climate change. These results, which were consistent across both

52 watersheds, can help inform planning and policies regarding land use, development, and

53 maintenance of hydrologic ecosystem services. 
Landscape scenarios and implications for streamflow in New England

1 Introduction

Changes to the landscape will affect water-related ecosystem services, and planning and

57 development must be informed by the range of potential effects to ensure resilient and sustainable water resources, especially under a changing climate. While climate and precipitation and are the primary drivers of the hydrologic cycle, land use and land cover modulate those signals and can exacerbate or mitigate the impacts (Brauman et al., 2007).

61 Watersheds concentrate precipitation inputs in space (regulating service), distribute them in time

62 (regulating service), and remove water via evapotranspiration (provisioning service). Through

63 modifications to infiltration capacity and vegetation cover, changes to land use and land cover

64 will affect the partitioning of water between evapotranspiration and streamflow along with the

65 timing of streamflows. An understanding of how plausible future landscapes and associated

66 ecosystem services might affect the water balance and streamflow can improve planning,

67 infrastructure design, and policy decisions.

An increase in vegetation cover tends to increase both evapotranspiration, which reduces

69 the provision of streamflow, and infiltration, which increases the temporal regulation of

70 streamflow. Paired watershed and observational studies generally show that a reduction in

71 vegetation cover leads to an increase in average streamflow due to the reduction in

72 evapotranspiration (e.g., Andréassin, 2004; Bosch \& Hewlett, 1982; Brown et al., 2005; Brown

73 et al., 2013; Bruijnzeel, 2004). In contrast, the effects of vegetation cover on low flows are less

74 certain due to the competing effects on evapotranspiration and infiltration (e.g., Devito et al.,

75 2005; Guswa et al., 2017; Homa et al., 2013; Jencso \& McGlynn, 2011; Laaha et al., 2013; Price,

76 2011; Smakhtin, 2001). The direction of the effect on flooding and high flows is more certain, as

77 vegetation increases evapotranspiration (reducing streamflow) and infiltration (reducing peak 
Landscape scenarios and implications for streamflow in New England

flows). The loss of vegetation, coupled with increases in impervious cover, increases peak

flows. The magnitude and significance of those services are uncertain across environments and events, however. For example, in the UK, increases in vegetation were found to reduce peak

81 flows for small to moderate rainfall events but had little effect for larger events (Dadson et al.,

82 2017). When the land is saturated, the regulating effect of infiltration may be reduced, and some

83 claim that landscape effects on flood reduction may be overestimated (Calder \& Aylward, 2006).

84 In one case, authors even found the opposite effect, with increased impervious area correlated

85 with decreased high flows, perhaps due to a concomitant increase in stormwater detention

86 infrastructure (Homa et al., 2013).

Investigators have also used modeling studies to elucidate the effects of land use on

88 hydrologic ecosystem services. Karlsson et al. (2016) examined the combined effect of four

89 land-use scenarios, four climate models, and three hydrological models on streamflows in

90 Denmark and found that the climate model had more influence than land-use change. Ashage et

91 al. (2018) used the Soil and Water Assessment Tool (SWAT) to show that forests and

92 woodlands, relative to agriculture, regulated both sediment loads and peak flows in Tanzania.

93 Baker \& Miller (2013) also used SWAT in East Africa and found that increases in urbanization

94 resulted in greater surface runoff and reduced groundwater recharge. For the Songkhram River

95 Basin in Thailand, Shrestha et al. (2018) employed SWAT to determine that the effects of

96 climate change (20\% decrease in streamflow) were greater than the effects due to potential land-

97 use changes ( $5 \%$ increase in streamflow). SWAT has also been applied to multiple watersheds

98 in the United States. In the northeast, an increase in forest cover led to a decrease in the severity

99 and duration of both high and low flows (Ahn \& Merwade, 2017). In southern Alabama, Wang

100 et al. (2014) showed that a near doubling of urban area from $26.4 \%$ of the landscape to $50.2 \%$ 
101 resulted in an increase of only $2.2 \%$ in the average daily flow. Hantush \& Kalin (2006)

102 simulated urbanization in the Pocono Creek in Pennsylvania, and they found that increasing

103 development from $5.8 \%$ of the landscape to $75.8 \%$ reduced average flows by $1.1 \%$ and increased

104 the average annual maximum daily flow by $19.4 \%$. Cheng (2013) used SWAT to simulate and

105 compare four land-use scenarios and three climate scenarios with respect to streamflow and

106 found that the effects of climate were greater than those due to land-use change. Building on that

107 work, Cheng et al. (2017) used SWAT to investigate the ability of stormwater detention to

108 mitigate the effects of climate change on high flows for the Charles River watershed in

109 Massachusetts.

110 In this work, we use SWAT to examine the effects of plausible, future land-use scenarios

111 on water-related ecosystem services for two watersheds in New England under both a historical

112 and potential future climate. The land-use scenarios were co-developed with scientists and a

113 range of stakeholders as part of the New England Landscape Futures (NELF) project, a large

114 research network designed to integrate diverse modes of knowledge and create a shared

115 understanding of how the future may unfold (McBride et al., 2019). Like all scenarios, the

116 NELF scenarios are not intended as forecasts or predictions; instead, they explore multiple

117 hypothetical futures in a way that recognizes the irreducible uncertainty and unpredictability of

118 complex systems (Thompson et al., 2012). Co-designing scenarios increases the range of

119 viewpoints included in the process and is widely credited with enhancing the relevance,

120 credibility, and salience of outcomes (Cash et al., 2003). Participatory development of land-use

121 scenarios is particularly useful in landscapes such as New England where change is driven by the

122 behaviors and decisions of thousands of independent land owners rather than by a central

123 decision-making authority. Throughout this paper, we use the term "scenarios" to refer to the 
Landscape scenarios and implications for streamflow in New England

124 stakeholder-informed future landscapes, and we use the term "simulations" to refer to the

125 combinations of climate-watershed-landscape used in our analyses.

In New England, where precipitation is abundant and consistent throughout the year,

127 stakeholders expressed that the primary water-quantity issues of concern are related to

128 stormwater, peak streamflow, and flooding. Consequently, this work focuses on effects of land

129 use on storm runoff and high flows. The intent is to reveal the magnitude and robustness of

130 potential effects due to plausible changes to the landscape. This work can provide one piece of a

131 more holistic and comprehensive assessment of ecosystem services across these land-use

132 scenarios (e.g., Thompson et al., 2014).

\section{Methods}

\section{$134 \quad 2.1 \quad$ Land-cover scenarios for New England in 2060}

McBride et al. (2017) and McBride et al. (2019) describe NELF's participatory process

136 for co-developing scenarios of future land cover in New England in 2060. In brief, four narrative

137 land-use scenarios were co-designed in context with a "Recent Trends" scenario using a scenario

138 development process that engaged over 150 stakeholders (e.g., conservationists, planners,

139 resource managers, land owners, scientists, etc.) from throughout the region. The scenarios were

140 created using the Intuitive Logics approach, a structured process in which participants develop

141 plausible storylines describing a set of distinct alternative futures (Schwarz, 1991). The NELF

142 participants used this process to construct four scenarios - Go It Alone (GA), Connected

143 Communities (CC), Yankee Cosmopolitan (YC), and Growing Global (GG) - characterized by

144 extreme states of two driver variables: (1) low to high natural resource planning and innovation

145 and (2) local to global socio-economic connectedness (Table 1), which they determined to be

146 among the most uncertain and potentially impactful for the region. Storylines for each scenario 
Landscape scenarios and implications for streamflow in New England

147 are provided in Table 1, which is adapted from the detailed narratives available in Fallon

148 Lambert et al. (2018).

149 Land uses for the scenarios were simulated using the cellular land-cover-change model,

150 Dinamica EGO v.2.4.1 (Soares-Filho et al. 2009; Soares-Filho et al., 2013), using a process that

151 iterated between modelers and stakeholders to ensure that the resulting maps accurately

152 represented the stakeholders' intent (Thompson et al., 2017). The 50-year simulations have 30-

153 m resolution and span the years 2010 to 2060 in ten-year time steps. Land cover varies across

154 five classes: High Density Development, Low Density Development, Forest, Agriculture, and

155 Legally Protected Land (e.g., conservation easements). Other land-cover classes, such as water,

156 were held constant throughout the simulations. For the Recent Trends scenario, the rate and

157 spatial patterns of land-cover transitions were based on observed changes in classified Landsat

158 data between 1990 and 2010 (Olofsson et al. 2016; Thompson et al., 2017).

\subsection{Study watersheds - Cocheco River and Charles River}

To investigate the effects of these plausible landscape scenarios (Table 1) on streamflow,

161 we selected the Cocheco River watershed, defined by USGS gage 01072800, and the Charles

162 River watershed, defined by USGS gage 01104500 (Figure 1). The Cocheco River watershed in

163 southeastern New Hampshire was selected because it is in one of the most rapidly urbanizing

164 parts of New England. The watershed has an area of $207 \mathrm{~km}^{2}$, and the main channel is $34 \mathrm{~km}$ in

165 length and drops $170 \mathrm{~m}$ in elevation from the headwaters to the gage at an elevation of $36.2 \mathrm{~m}$.

166 Average annual precipitation is $1059 \mathrm{~mm} /$ year, and average streamflow is $3.14 \mathrm{cms}$, equivalent

167 to $479 \mathrm{~mm} /$ year. The Charles River flows through some of the most densely populated parts of

168 New England, and a SWAT model had previously been calibrated to study this watershed

169 (Cheng et al., 2017). The watershed has an area of $648 \mathrm{~km}^{2}$, and it is flatter and more developed 
Landscape scenarios and implications for streamflow in New England

171 drops only $101 \mathrm{~m}$ over its $108-\mathrm{km}$ length. Average annual precipitation is $1111 \mathrm{~mm} / \mathrm{year}$, and

172 average streamflow is $8.01 \mathrm{cms}$, equivalent to $389 \mathrm{~mm} /$ year. Figures 2 and 3 display the land

173 uses across the Cocheco River and Charles River watersheds for the landscape scenarios

174 described above. Table 2 reports the fraction of each land-use type within the watersheds.

\subsection{Hydrologic model - SWAT}

This project employed the Soil and Water Assessment Tool (SWAT; Arnold et al., 1998;

177 Nietsch et al., 2011) to represent the effects of land-cover differences on hydrology. SWAT is a

178 well-known and proven process-based model that represents weather, hydrology, growth and

179 seasonality of vegetation, and landscape management practices. It operates with a daily time

180 step, and space is represented in a semi-distributed way. Within a watershed, sub-basins are

181 linked via a stream network, and each sub-basin is represented by a collection of Hydrologic

182 Response Units (HRUs). Each HRU comprises a particular combination of soil, slope, land use,

183 and land management. Within a sub-basin, HRUs are not represented explicitly in space and do

184 not interact with each other, and water-balance equations are solved within each HRU. Incoming

185 precipitation is partitioned among canopy interception, storm runoff, and storage in the soil. Soil

186 water then contributes to lateral subsurface flow, groundwater return flow, and deep recharge.

188 parameters related to land use, including runoff (USDA, 2004), which depends on soil and land use; 
Landscape scenarios and implications for streamflow in New England

- The fraction of impervious area and the fraction of impervious area that is directly connected to storm sewer infrastructure; these parameters affect the aggregated curve number for urban areas;

- Vegetation, which affects the seasonality and magnitude of evapotranspiration.

Across different landscape scenarios, the weather, topography, soils, and soil-related parameters are held constant.

\subsubsection{Weather forcing}

Simulations were run in SWAT for twenty-year periods for both historical weather and a future climate. The first three years of all simulations were used as a warm-up period and were not used in subsequent analyses. The years were selected so that the final simulated years coincided with the years of the landcover datasets plus the eight years before and the eight years after (2002-2017 for the historical weather and 2052-2067 for the simulated future climate).

Data for the historical weather came from the National Oceanic and Atmospheric Administration's Climate Data Online Search webtool (NOAA, 2018). We used data from the Rochester Skyhaven Airport (054791) weather station for the Cocheco River watershed and the Boston (14739) weather station for the Charles River watershed. Precipitation and temperature data for a possible future climate were obtained from the USGS Geo Data Portal Bias Corrected Constructed Analogs V2 Daily Climate Projections dataset (USGS, 2018). The spatially and temporally downscaled LOCA CMIP5 CCSM4 RCP 8.5 dataset has among the highest temperature correlations with observed data (Kumar et al., 2013) and performs well with comparisons to historical and paleo climate data (Sillmann et al., 2013).

Precipitation and temperature data were used with the weather generator in SWAT (using the WGEN_US_FirstOrder database) to simulate additional weather parameters, including 
Landscape scenarios and implications for streamflow in New England

214 relative humidity, wind speed, and solar radiation. The Penman-Monteith method was used to

215 estimate potential evapotranspiration (Arnold et al., 2012).

\subsubsection{Landscape features and watershed discretization}

219 and considered swamps to be forests, we separated water and wetlands, and accounted for

220 herbaceous wetlands and swamps explicitly by extracting those land-cover types from the

221 National Land Cover Database (NLCD; Homer et al., 2015) and imposing them on the NELF

222 scenarios. Soil data were obtained from the SSURGO database (USDA, 2014). Three slope

223 classes were calculated for each watershed using natural class breaks; breakpoints of 5.7\% and

$22414.1 \%$ were used for the Cocheco River watershed and 4.6\% and 11.5\% for the Charles River

225 watershed. To better represent the small land-use patches that are typical of the New England

226 landscape, we did not merge smaller HRUs with larger neighbors, as is sometimes done.

229 2012). We chose curve numbers (CN2) to reflect conditions in New England. Because there is

230 very little woodland pasturing in New England, we changed the CN2 values for generic forest

231 (FRST) from the default values in SWAT, which would be appropriate in forests subject to

232 grazing by livestock ("fair" condition), to those for forests without livestock grazing ("good"

233 condition). CN2 values for forest were 5, 55, 70, 77 for soil hydric classes A through D,

234 respectively.

235 The New England Landscape Futures use a single designation for all agricultural land,

236 and we do the same by using the generic agriculture land-cover (AGRL). The default curve 
Landscape scenarios and implications for streamflow in New England

237 numbers for AGRL in SWAT are appropriate for farmland dominated by corn or row crops,

238 while New England farms are primarily pasture and hay fields. Therefore, we updated this

239 parameter by using county-level data from the United States Agricultural Census (USDA, 2018)

240 to determine an area-weighted curve number based on the actual agricultural types. Resulting

241 curve numbers for our agricultural land use are 42.3, 65.1, 76.2, and 82.1 for soil hydric classes

242 A through D, respectively. Other parameters in SWAT's vegetation database (plant.dat) were

243 not changed.

Urban areas in the NELF scenarios are designated as either "high-density development"

245 or "low-density development." We consider these two classes to be analogous to Urban

246 Residential High Density (URHD) and Urban Residential Medium/Low Density (URML),

247 respectively, in SWAT. We calculated the fraction of impervious surface for all of New England

248 by overlaying the NLCD urban landcover types (Homer et al., 2015) on the NLCD 2011 Percent

249 Developed Imperviousness GIS layer (Xian et al., 2011) and calculating separate area-weighted

250 averages for URHD (consisting of the NLCD "Developed, High Intensity") and URML

251 (consisting of NLCD “Developed, Open Space”, "Developed, Low Intensity”, and "Developed

252 Medium Intensity"). This resulted in 88.9\% impervious for URHD and $27.5 \%$ impervious for

253 URML in our simulations. For all scenarios except Connected Communities and Yankee

254 Cosmopolitan, the fractions of connected impervious area (i.e., the impervious area that is

255 directly connected to storm sewers) were left at SWAT's default values of $44 \%$ and $17 \%$,

256 respectively, for URHD and URML. For Connected Communities and Yankee Cosmopolitan,

257 those numbers were halved to $22 \%$ and $8.5 \%$ to represent natural-resource innovation (Table 1)

258 and the implementation of green infrastructure, such as bioswales and rain gardens. CN2 values

259 for the pervious portions of these urban areas were set to 39, 61, 74, 80 for hydric classes $\mathrm{A}$ 
Landscape scenarios and implications for streamflow in New England

261 grass-covered lawns with greater than 75\% grass cover (Arnold et al., 2012). No other values in

262 the urban.dat file were changed.

\subsubsection{Calibration and model performance under historic conditions}

To increase model performance and accuracy, parameters that were unrelated to land cover within the SWAT model were calibrated by matching simulated streamflow to observed streamflow under current land use. Model parameters were calibrated separately for each watershed using observed flow for the years 2002-2011 and validated using the observed flow

268 from 2012-2017. Parameters that were explicitly related to land use, such as the curve number

269 and vegetation-related parameters, were not included in calibration, since they were our driver

270 variables of interest. We used a semi-automated approach with the SWAT Calibration and

271 Uncertainty Program (SWAT-CUP) using the SUFI-2 optimization method (Abbaspour, 2015).

272 Starting values for our calibration were either the default values in SWAT or the calibrated 273 results from an earlier study on the Charles River (Cheng, et al., 2017). We used the Nash-

274 Sutcliffe efficiency, percent bias, and the ratio of the root-mean-square error to the standard

275 deviation of the streamflow observations (RSR) as metrics of goodness-of-fit. Calibration

276 continued until none of the metrics improved by more than $5 \%$ over the previous iteration.

277 The final model for the Cocheco River had a NSE of 0.58, RSR of 0.64, and percent bias

278 of $-13.6 \%$ for the calibration period. The model for the Charles River had values of $0.74,0.51$,

279 and $1.2 \%$, respectively. Moriasi et al. (2007) suggest that a model can be viewed as satisfactory

280 if the NSE value is greater than 0.50 , the RSR is less than 0.70 , and the percent bias is less than

281 plus or minus 25\%; the calibrated models for both rivers were deemed satisfactory. For the

282 validation period, the Cocheco River had a NSE of 0.49 , RSR of 0.72 , and percent bias of - 
Landscape scenarios and implications for streamflow in New England

$28319.5 \%$, and the Charles River had values of $0.74,0.51$, and $23.3 \%$ respectively. Final parameters

284 and goodness-of-fit metrics are shown in Table 3.

\subsection{Streamflow metrics of interest}

Across scenarios and climates, we consider two metrics of hydrologic regulation. The

287 first is the water balance - the partitioning of precipitation among evapotranspiration, storm

288 runoff, and baseflow. Runoff and baseflow together constitute streamflow; storm runoff is the

289 rapid response to precipitation events, whereas baseflow represents the slower component of

290 streamflow driven by seasonal and interannual variability. The second metric is the annual

291 maximum daily flow. While true peak flows may be short-lived phenomena - on the scale of

292 minutes to hours - the annual maximum daily flow nonetheless provides an indication of the

293 potential for flooding and associated damage.

\section{Results}

\section{$295 \quad 3.1 \quad$ Water balance}

Across the simulations, land use has little effect on the average partitioning of

297 precipitation between evapotranspiration and streamflow (Figure 4). Under historic weather,

298 simulated evapotranspiration is $44-45 \%$ of precipitation in the Cocheco River watershed and 46-

$29948 \%$ of precipitation in the Charles River watershed with little variation among land-use

300 scenarios (Table 5). For the future climate, annual precipitation increases from $1059 \mathrm{~mm}$ to

$3011194 \mathrm{~mm}$ in the Cocheco River watershed and $1111 \mathrm{~mm}$ to $1345 \mathrm{~mm}$ in the Charles River

302 watershed, and potential evaporation decreases (Table 5). As a result, evaporation represents a

303 smaller fraction $(35 \%-36 \%)$ of precipitation for the simulations with a future climate. 
Landscape scenarios and implications for streamflow in New England

While total streamflow is nearly unchanged across the land-use scenarios, the partitioning

305 of streamflow between baseflow and storm runoff does vary. In the Cocheco River watershed,

306 baseflow is $90-94 \%$ of streamflow for all land-use scenarios, except Growing Global, for both

307 historic and future weather. For Growing Global, baseflow is $74 \%$ and $78 \%$ of streamflow for

308 historic weather and a future climate, respectively. In the more developed Charles River

309 watershed, baseflow represents between $40 \%$ and $61 \%$ of streamflow under historic weather,

310 with the lowest fraction associated with the Growing Global scenario (Table 5). For the future

311 climate, both storm runoff and baseflow increase. As a fraction of streamflow, the baseflow

312 contribution increases by approximately $10 \%$ and shows variability across scenarios similar to

313 that under historic weather.

314 Seasonal water balances exhibit behavior similar to the annual water balances.

315 Differences in land use have little effect on the partitioning of water between streamflow and

316 evapotranspiration; rather, the effect is in the separation of streamflow into baseflow and storm

317 runoff (Table 6 and 7). The increases in streamflow associated with a future climate vary

318 seasonally, with large increases in autumn and winter, moderate increases in spring, and little

319 effect in summer (Figure 5). For historic weather, streamflow during the fall and winter

320 represents $40 \%$ and $44 \%$ of annual streamflow for the Cocheco River and Charles River

321 watersheds, respectively. Those fractions increase to $51 \%$ and $55 \%$ under a future climate

322 (Figure 5).

3.2 Changes in magnitude of annual maximum daily flow

The annual maximum daily flow (AMDF) exhibits significant year-to-year variability due

325 to variability in weather and precipitation. Under historic weather and land use, simulated

326 AMDFs range from 10.7 to $78.2 \mathrm{~m}^{3} / \mathrm{s}$ (equivalent to 4.5 to $32.7 \mathrm{~mm} /$ day) for the Cocheco River 
Landscape scenarios and implications for streamflow in New England

327 watershed and 15.5 to $94.0 \mathrm{~m}^{3} / \mathrm{s}$ (2.1 to $12.5 \mathrm{~mm} /$ day) for the Charles River watershed. Due to 328 this year-to-year variability, a paired comparison was used to quantify the effect of land use on

329 AMDF. For each year of simulation, the difference in AMDF between each future land-use

330 scenario and the land use from 2010 indicates the effect of land-use change on high flows.

331 Figures 6 and 7 present the average differences, along with their 95\%-confidence intervals

332 determined via 10,000 bootstrap samples, expressed as a percent of the average AMDF under

333 land use in 2010.

334 Analysis of the difference in these flows between land use in 2010 and future scenarios

335 indicates that land-use change could have a moderate effect on the annual maximum daily flow

336 (Figures 6 and 7 and Table 8). Under the Growing Global scenario, the annual maximum daily

337 flows are approximately 10\% larger than those under the historic land-use scenario. This result

338 is robust across both the Cocheco River and Charles River watersheds and both historic and

339 future climates. Effects under other land-use scenarios are more modest, with mean values

340 ranging from $0-4 \%$.

341 While the AMDFs increase with increasing urbanization, the relationship depends on the

342 nature of the urbanization - whether high density or medium or low density - and the associated

343 increases in the fraction of impervious area (Figure 8). For example, while total urban area is

344 greater for both the Recent Trends and Go-It-Alone scenarios than for Connected Communities

345 (Table 2), the Connected Communities scenario has a higher proportion of high-density

346 development, and a comparable fraction of total impervious area (Table 8 and Figure 8). The

347 incorporation of green infrastructure, manifest as a lower fraction of directly connected

348 impervious area in the Yankee Cosmopolitan and Connected Communities scenarios, mitigates

349 the effect of urbanization on AMDF only slightly. 
Landscape scenarios and implications for streamflow in New England

\section{Discussion}

\subsection{Differences among land-use scenarios}

Variations in the future land-use scenarios have little effect on the overall water balance and provisioning of streamflow. The dominant effect of land-use is on the temporal regulating

354 service: partitioning streamflow between faster storm runoff and slower baseflow (Table 5 and

355 Figure 4). The effects on these services are similar across the two climates and two watersheds.

356 Increases in urban areas lead to more water moving quickly to the streams, which increases the

357 magnitude of the annual maximum daily discharge. This effect reaches a maximum of

358 approximately $10 \%$ for both the Cocheco and Charles River watersheds when comparing land

359 use in 2010 with the Growing Global scenario.

The relative sensitivity of AMDF to impervious area is $2 \%$ for the Cocheco River

361 watershed and 6\% for the Charles River watershed (for both historic weather and a future

362 climate). Thus, a large change in impervious area is required to generate a noticeable effect on

363 the annual maximum daily flow (Table 8). These results are consistent with those of Hantush

364 and Kalin (2006) who found a relative sensitivity of AMDF to developed area of 2\% in

365 Pennsylvania. Part of the reason for these limited sensitivities may be that high flows in New

366 England and the northeast occur predominantly in March and April when evapotranspiration is

367 low and the ground is saturated. Under such conditions, the regulating service associated with

368 infiltration is reduced. Sensitivity of AMDF to precipitation is much greater: $40-60 \%$ for the

369 Cocheco River watershed and over $80 \%$ for the Charles River. Even though the sensitivities are

370 quite different, the effects on AMDF of plausible future changes in land use or climate in 2060

371 are comparable, with effects due to land-use change reaching $10 \%$ and effects attributable to 
372 climate change of approximately 5\% for the Cocheco River and $17 \%$ for the Charles River

373 (Table 8).

\section{$374 \quad 4.2 \quad$ Implications of findings for policy and design}

The results of this work indicate that the effects of climate and land use on runoff and

376 high flows are additive (Table 8). The combination of a wetter future climate and increased

377 urbanization has the potential to exacerbate high flows and flooding. While the results imply

378 that it would take a major reworking of the landscape to mitigate the effects of climate change,

379 they also indicate that rapid growth and development could present significant challenges for

380 stormwater management and existing infrastructure. If population growth is modest, land-use

381 decisions and development patterns have little effect on storm runoff and high flows (compare

382 scenarios CC and GA in Table 5 and Figures 6 and 7). However, when the future is

383 characterized by global socio-economic connectedness and increased population growth (Table

384 1), the results from the Yankee Cosmopolitan and Growing Global scenarios are substantively

385 different (Table 5 and Figures 6 and 7). In this case, urban planning and choices regarding land

386 use can have a large impact on regulating services and the potential for flooding. Planning for

387 smart and sustainable growth while concomitantly investing in multi-functional landscapes and

388 natural infrastructure could reduce flood damages. Additionally, with increased high flows,

389 communities may need to increase the size of their water infrastructure and/or allow for short

390 periods of inundation (Rosenzweig et al., 2018).

\section{$391 \quad 4.3 \quad$ Limitations of approach}

This study employs a hydrologic model to investigate the potential impacts of future

393 land-use scenarios on streamflow. As such, the utility of the results depends upon the 
Landscape scenarios and implications for streamflow in New England

394 appropriateness of the mathematical representation of watershed characteristics and processes.

395 SWAT is a well-established model, suitable for watershed applications, that has been and

396 continues to be employed in a number of studies and investigations. Nonetheless, there are some

397 inherent limitations of the model, and the results of this work should be interpreted within that

398 context.

399 First, some of the model parameters (such as available water content, hydraulic

400 conductivity, and surface runoff lag) are determined by calibrating the model to existing

401 conditions. Using the model to represent future land use presumes that those parameters are

402 unchanging across the scenarios. In most cases, we anticipate this to be true, as those parameters

403 are functions of soil, topography, or other watershed characteristics that are generally unchanged

404 as the land cover changes. Characteristics that do change with land use, such as the curve

405 number and vegetation cover, are not calibrated but determined a priori. Second, the temporal

406 resolution of this work is limited to the daily timescale. This precludes the representation of sub-

407 daily dynamics of precipitation and streamflow. Therefore, instantaneous peak streamflows

408 cannot be modeled, and this work is limited to daily discharge. Third, SWAT represents space in

409 a semi-distributed way. While the model accounts for spatial variations among watershed

410 characteristics, the HRU structure does not permit the representation of the spatial arrangement

411 and connectedness of landscape elements. Therefore, feedbacks and interactions among

412 different parts of the landscape cannot be represented explicitly. For example, increased runoff

413 from one HRU cannot infiltrate in a different HRU. Such interactions can only be represented

414 implicitly. Relatedly, storm runoff is represented with an approach that implicitly accounts for

415 effects of soil, land cover, and land management through a single parameter. This is consistent 
Landscape scenarios and implications for streamflow in New England

416 with large-scale analyses and is not intended for small-scale green-infrastructure evaluation.

417 Results from this work must be interpreted within the context of these modeling limitations.

\section{$418 \quad 4.4 \quad$ Next steps}

Our results reveal that potential changes to high flows are strongly connected to increases

420 in urban land uses in New England. To more precisely elucidate the effects of such changes in

421 land use and land cover, one could refine the representation of urban hydrology. Models such as

422 the Storm Water Management Model (SWMM) and HydroCAD are better equipped to represent

423 the natural and engineered features of an urban landscape, the sub-daily dynamics of the runoff

424 response to storm events, and the elements of green infrastructure at the site and local scales.

425 Such site-scale and sub-daily simulations of hydrological responses can further inform policy

426 and practice, and these more detailed studies will necessarily be narrower in geographic scope.

427 Continued engagement with stakeholders in the scenario-planning process can provide guidance

428 to locations of interest along with the level of risk and types of landscape and infrastructure

429 interventions that communities are willing to accept.

430 Finally, changes to nutrient and sediment loads are additional effects of changes to the

431 landscape that may be of interest to stakeholders in New England. SWAT could be employed

432 (for the Charles River, Cocheco River, or other watersheds) to investigate the effects of the

433 landscape scenarios on the export of nitrogen, phosphorus, and sediment. The effects on water

434 quality could be combined with our results on high flows to create a more complete picture of

435 the effects of landscape futures on water-related services. 
Landscape scenarios and implications for streamflow in New England

\section{Conclusions}

Application of a hydrologic model to stakeholder-developed scenarios can provide

438 meaningful insight to the effects of plausible land-use changes on water-related ecosystem

439 services. The combination of land use and climate change on storm runoff, high flows, and

440 flooding are issues of concern, not only in New England but worldwide. Across the NELF

441 scenarios, variations in land use had little effect on the overall water balance. Rather, the impact

442 was on high flows and the partitioning of streamflow between storm runoff and baseflow. Those

443 effects were correlated with the amount of impervious cover. For most of the scenarios (GA,

$444 \mathrm{CC}, \mathrm{YC})$, the effects were muted and less than the effects due to climate change. For the

445 Growing Global scenario, however, the effects were large and comparable to or greater than the

446 effects of climate. These responses to land-cover change were similar across the Cocheco River

447 and Charles River watersheds. Results from this work can help inform designs and decisions

448 related to infrastructure resiliency and can complement other studies to provide a comprehensive

449 assessment of ecosystem services across possible future landscapes.

\section{Acknowledgements}

This research was supported, in part, by Highstead, the National Science Foundation

452 Harvard Forest Long Term Ecological Research Program (Grant No. NSF-DEB 18-32210), and

453 the Scenarios Society and Solutions Research Coordination Network (Grant No. NSF-DEB-13-

454 38809). The authors would also like to thank Dr. James Dennedy-Frank for his helpful

455 comments. 


\section{References}

1. Abbaspour, K. C. (2015). SWAT-CUP: SWAT Calibration and Uncertainty Programs - A User Manual. EAWAG.

2. Andréassin, V. (2004). Water and forests: From historical controversy to scientific debate, Journal of Hydrology, 291(1), 1-27, doi:10.1016/j.hydrol.2003.12.015.

3. Anh, K-H., \& Merwade, V. (2017). The effect of land cover change on the duration and severity of high and low flows, Hydrological Processes, 31, 133-149, doi:10.1002/hyp.10981.

4. Arnold, J. G., Srinivasan, R., Muttiah, R. S. \& Williams, J. R. (1998). Large-area hydrologic modeling and assessment: Part I. Model development, J. American Water Resour. Assoc. 34(1): 73-89.

5. Arnold, J. G., Moriasi, D. N., Gassman, P. W., Abbaspour, K. C., White, M. J., Srinivasan, R., Santhi, C., Harmel, R. D., van Griensven, A., Van Liew, M. W., Kannan, N. \& Jha, M. K. (2012). SWAT: Model use, calibration, and validation, Transactions of the ASABE, 55(4), 1491-1508.

6. Ashagre, B. B., Platts, P. J., Njana, M., Burgess, N. D., Balmford, A., Turner, R. K., Schaafsma, M. (2018). Integrated modelling for economic valuation of the role of forests and woodlands in drinking water provision to two African cities, Ecosystem Services, 32, 50 61.

7. Baker, T. J., \& Miller, S. N. (2013). Using the Soil and Water Assessment Tool (SWAT) to assess land use impact on water resources in an East African watershed, Journal of Hydrology, 486, 100-111, doi:10.1016/j.jhydrol.2013.01.041

8. Bosch, J.M., \& Hewlett, J.D. (1982). A review of catchment experiments to determine the effect of vegetation changes on water yield and evapo-transpiration, Journal of Hydrology, 55(1-4), 3-23.

9. Brauman, K., Daily, G. C., Duarte, T. K., Mooney, H. A. (2007). The nature and value of ecosystem services: An overview highlighting hydrologic services, Annual Review of Environment and Resources, 32, 67-98.

10. Brown, A. E., Western, A. W., McMahon, T. A., Zhang, L. (2013). Impact of forest cover changes on annual streamflow and flow duration curves. Journal of Hydrology, 483, 39-50.

11. Brown, A. E., Zhang, L., McMahon, T. A., Western, A. W., Vertessy, R. A. (2005). A review of paired catchment studies for determining changes in water yield resulting from alterations in vegetation, Journal of Hydrology, 310, 28-61, doi: 10.1016/j.jhydrol.2004.12.010.

12. Bruijnzeel, L. A. (2004). Hydrological functions of tropical forests: not seeing the soil for the trees? Agriculture, Ecosystems and Environment, 104, 185-228.

13. Calder, I. R., Aylward, B. (2006). Forest and floods: Moving to an evidence-based approach to watershed and integrated flood management. Water Int. 31, 87-99.

14. Cash, D. W., Clark, W. C., Alcock, F., Dickson, N. M., Eckley, N., Guston, D. H., Jäger, J. \& Mitchell, R. B. (2003). Knowledge systems for sustainable development. Proceedings of the 
National Academy of Sciences, 100(14), 8086- 8091.

http://dx.doi.org/10.1073/pnas.1231332100.

15. Cheng, C. (2013). Social vulnerability, green infrastructure, urbanization and climate change-induced flooding: A risk assessment for the Charles River watershed, Massachusetts, USA (doctoral dissertation). Retrieved from Scholarworks at University of Massachusetts Amherst. //scholarworks.umass.edu/open_access_dissertations/781/

16. Cheng, C., Yang, E. Y.-C., Ryan, R. L., Yu, Q. \& Brabec, E. (2017). Assessing climate change-induced flooding mitigation for adaptation in Boston's Charles River Watershed. Landscape and Urban Planning, 167, 25-36. doi: 10.1016/j.landurbplan.2017.05.019

17. Dadson, S. J., Hall, J. W., Murgatroyd, A., Acreman, M., Bates, P., Beven, K., Heathwaite, L., Holden, J., Holman, I. P., Lane, S. N., O’Connell, E., Penning-Roswell, E., Reynard, N., Sear, D., Thorne, C., Wilby, R. (2017). A restatement of the natural science evidence concerning catchment-based "natural" flood management in the UK. Proc. R. Soc. 473, 31. doi:10.1098/rspa.2016.0706

18. Devito, K., Creed, I., Gan, T., Mendoza, C., Petrone, R., Silins, U., Smerdon, B. (2005). A framework for broad-scale classification of hydrologic response units on the Boreal Plain: is topography the last thing to consider? Hydrological Processes, 19, 1705-1714, doi:10.1002/hyp.5881.

19. Fallon Lambert K., McBride M. F., Weiss, M., Thompson, J. R., Theoharides, K. A., Field, P. (2018). Voices from the Land: Listening to New Englanders' Views of the Future. Harvard Forest, Harvard University and the Science Policy Exchange. ISBN: 978-96214667-5.

20. Guswa, A. J., Hamel, P., Dennedy-Frank, P. J. (2017). Potential effects of landscape change on water supplies in the presence of reservoir storage, Water Resources Research, doi:10.1002/2016WR019691.

21. Hantush, M. M. \& Kalin, L. (2006). Impact of urbanization on the hydrology of Pocono Creek watershed: a model study. USEPA Final Report EPS/600/R-07/006. National Risk Management Research Laboratory, Office of Research and Development, U.S. Environmental Protection Agency, Cincinnati, Ohio, 45268.

22. Homa, E. S., Brown, C., McGarigal, K., Compton, B. W., Jackson, S. D. (2013). Estimating hydrologic alteration from basin characteristics in Massachusetts, Journal of Hydrology, 503, 196-208, doi: 10.1016/j.jhydrol.2013.09.008.

23. Homer, C. G., Dewitz, J. A., Yang, L., Jin, S., Danielson, P., Xian, G., Coulston, J., Herold, N. D., Wickham, J. D., and Megown, K. (2015). Completion of the 2011 National Land Cover Database for the conterminous United States-Representing a decade of land cover change information. Photogrammetric Engineering and Remote Sensing, v. 81, no. 5, 345354.

24. Jencso, K. G., McGlynn, B. L. (2011). Hierarchical controls on runoff generation: Topographically driven hydrologic connectivity, geology, and vegetation. Water Resources Research. 47, W11527, doi:10.1029/2011WR010666. 
Landscape scenarios and implications for streamflow in New England

25. Karlsson, I. B., Sonnenborg, T. O., Refsgaard, J. C., Trolle, D., Børgesen, C. D., Olesen, J. E., Jeppesen, E., Jensen, K. H. (2016). Combined effects of climate models, hydrological model structures and land use scenarios on hydrological impacts of climate change. Journal of Hydrology, 535, 301-317, doi:10.1016/j.jhydrol.2016.01.069

26. Kumar, S., Merwade, V., Kinter, J., Niyogi, D. (2013). Evaluation of temperature and precipitation trends and long-term persistence in CMIP5 twentieth-century climate simulations. Journal of Climate, 26(12), 4168-4185 doi: 10.1175/JCLI-D-12-00259.1

27. Laaha, G., Demuth, S., Hisdal, H., Kroll, C. N., van Lanen, H. A. J., Nester, T., Rogger, M., Sauquet, E., Tallaksen, L. M., Woods, R. A., Young, A. (2013). Prediction of low flows in ungauged basins, in Runoff Prediction in Ungauged Basins: Synthesis across Processes, Places, and Scales, G. Blöschl, M. Sivapalan, T. Wagener, A. Viglione, H. Savenije eds., Cambridge University Press, Cambridge, UK.

28. McBride, M. F., Fallon Lambert, K., Huff, E. S., Theoharides, K. A., Field, P., and Thompson, J. R. (2017). Increasing the effectiveness of participatory scenario development through codesign. Ecology and Society 22.

29. McBride, M. F., Duveneck, M. J., Lambert, K. F., Theoharides, K. A. and Thompson, J. R. (2019). Perspectives of resource management professionals on the future of New England's landscape: Challenges, barriers, and opportunities. Landscape and Urban Planning, 188, 3042, https://doi.org/10.1016/j.landurbplan.2018.10.019

30. Moriasi, D.N., Arnold, J.G., Van Liew, M.W., Bingner, R.L., Harmel, R.D., Veith, T.L. (2007). Model evaluation guidelines for systematic quantification of accuracy in watershed simulations. Transactions of the ASABE. 50(3):885-900.

31. Narsimlu, B., Gosain, A. K. \& Chahar, B. R. (2013). Assessment of Future Climate Change Impacts on Water Resources of Upper Sind River Basin, India Using SWAT Model. Water Resour Manage. 27: 3647. doi.org/10.1007/s11269-013-0371-7.

32. Neitsch, S. L., Arnold, J. G., Kiniry, J. R., Williams, J. R., (2011). Soil and Water Assessment Tool - Theoretical Documentation, version 2009, Texas Water Resources Institute Technical Report No. 406.

33. NOAA (2018). National Centers For Environmental Information. Climate Data Online Search. https://www.ncdc.noaa.gov/cdo-web/search/ Accessed [1/19/2018].

34. Olofsson, P., Holden, C. E., Bullock, E. L., and Woodcock, C. E. (2016). Time series analysis of satellite data reveals continuous deforestation of New England since the 1980s. Environmental Research Letters 11:1-8.

35. Plisinski, J., McBride, M. F., Morrele, L., Duveneck, M. J., \& Thompson, J. R. (2017) New England Landscape Futures Land Cover Maps. Harvard Forest. DOI 10.5281/zenodo.890897

36. Price, K. (2011). Effects of watershed topography, soils, land use, and climate on baseflow hydrology in humid regions: A review, Progress in Physical Geography, 35(4), 465-492, doi: $10.1177 / 0309133311402714$.

37. Rosenzweig, B. R., McPhillips, L., Chang, H., Cheng, C., Welty, C., Matsler, M., Iwaniec, D., \& Davidson, C. (2018). Urban pluvial flood risk and opportunities for resilience. WIREs. doi:10.1002/wat2.1302 
38. Schwarz, P. (1991). The art of the long view: planning for the future in an uncertain world. Currency Doubleday, New York.

39. Shrestha, S., Bhatta, B., Shrestha, M., Shrestha, P. K. (2018). Integrated assessment of the climate and landuse change impact on hydrology and water quality in the Songkhram River Basin, Thailand, Science of the Total Environment, 643, 1610-1622, doi:10.1016/j.scitotenv.2018.06.306

40. Sillmann, J., Kharin, V. V., Zhang, X., Zweirs, F. W., and Bronaugh, D. (2013). Climate extremes indices in the CMIP5 multimodel ensemble: Part 1. Model evaluation in the present climate. Journal of Geophysical Research: Atmospheres 118: 1716-1733.

41. Smahktin, V.U. (2001). Low flow hydrology: a review, Journal of Hydrology, 240, 147-186.

42. Soares-Filho, B., Rodrigues, H., and Follador, M. (2013). A hybrid analytical-heuristic method for calibrating land-use change models. Environmental Modelling \& Software 43:8087.

43. Soares-Filho, B. S., Rodrigues, H. O., and Costa, W. L. (2009). Modeling Environmental Dynamics with Dinamica EGO, 120 pp.

44. Thompson, J. R., Wiek, A., Swanson, F., Carpenter, S. R., Fresco, N., Hollingsworth, T. N., Spies, T. A. \& Foster, D. R. (2012). Scenario studies as a synthetic and integrative research activity for long-term ecological research. BioScience 62:367-376.

45. Thompson, J. R., Lambert, K. F., Foster, D., Blumstein, M., Broadbent, E., Zambrano, A. A., (2014). Changes to the Land: Four Scenarios for the Future of the Massachusetts Landscape, Harvard Forest, Harvard University, Petersham, MA, 38 pages.

46. Thompson, J. R., Plinskski, J., Olofsson, P., Holden, C. E., \& Duveneck, M. J. (2017). Forest loss in New England: A projection of recent trends. PLoS ONE 12:1-17.

47. USDA (2004). United States Department of Agriculture, Natural Resources Conservation Service, Chapter 10, Estimation of direct runoff from storm rainfall, National Engineering Handbook, Part 630 Hydrology, Available online at http://www.wcc.nrcs.usda.gov/ftpref/wntsc/H\&H/NEHhydrology/ch10.pdf Accessed [3/14/2016].

48. USDA (2014). United States Department of Agriculture, Natural Resources Conservation Service, SSURGO Soils. Web Soil Survey. Available online at https://www.nrcs.usda.gov/wps/portal/nrcs/main/soils/survey/. Accessed [3/24/2014]

49. USDA (2018). United States Department of Agriculture, National Agricultural Statistics Service. Census of Agriculture. Available online at https://www.nass.usda.gov/Publications/AgCensus/2012/Full_Report/Volume 1, Chapter 2 County_Level/. Accessed [4/23/2018].

50. USGS (2018). US Geological Survey, USGS Geo Data Portal. Bias Corrected Constructed Analogs V2 Daily Climate Projections. Available online at https://cida.usgs.gov/gdp/client/\#!catalog/gdp/dataset/54dd5dece4b08de9379b38d5. Accessed [1/29/2018]. 
51. Wang, R., Kalin, L., Kuang, W., Tian, H. (2014). Individual and combined effects of land use/cover and climate change on Wolf Bay watershed streamflow in southern Alabama. Hydrol. Process. 28 (5530-5546). doi: 10.1002/hyp.10057

52. Xian, G., Homer, C., Dewitz, J., Fry, J., Hossain, N., and Wickham, J. (2011). The change of impervious surface area between 2001 and 2006 in the conterminous United States. Photogrammetric Engineering and Remote Sensing, Vol. 77(8): 758-762.

53. Zambrano-Bigiarini, M. (2017). Goodness-of-Fit Functions for Comparison of Simulated and Observed Hydrological Time Series. CRAN.R. Available online at https://cran.rproject.org/web/packages/hydroGOF/index.html. Accessed [12/1/2017]. 
Landscape scenarios and implications for streamflow in New England

\section{Tables}

Table 1. Storylines for New England Landscape Futures in 2060. Scenario icons and descriptions are adapted with permission from Fallon Lambert et al. (2018).

Table 2. Fractional land use across scenarios and watersheds.

Table 3. Calibrated parameters for SWAT models of the Cocheco River and Charles River watersheds.

Table 4. Goodness-of-fit for SWAT models of the Charles River and Cocheco River watersheds. NSE is the Nash-Sutcliffe efficiency, and RSR is the ratio of the root-mean-squared error to the standard deviation of the observations. All goodness-of-fit statistics were calculated in $\mathrm{R}$ with the hydroGOF package (Zambrano-Bigiarini, 2017).

Table 5. Average annual fluxes across simulations. HW and FC indicate simulations under historic weather and a future climate, respectively. Scenarios are denoted as follows: $2010-$ historic land use in 2010, RT - Recent Trends, GA - Go It Alone, CC - Connected Communities, YC - Yankee Cosmopolitan, GG - Growing Global.

Table 6. Seasonal evapotranspiration (ET), storm runoff(SR), and baseflow (BF), in mm, for the Cocheco River watershed.

Table 7. Seasonal evapotranspiration (ET), storm runoff (SR), and baseflow (BF), in mm, for the Charles River watershed.

Table 8. High-density urban area (URHD), medium/low density urban area (URML), impervious area, and average annual maximum daily flow across the simulations. Scenarios are denoted as follows: 2010 - historic land use in 2010, RT - Recent Trends, GA - Go It Alone, CC Connected Communities, YC - Yankee Cosmopolitan, GG - Growing Global. 
bioRxiv preprint doi: https://doi.org/10.1101/847186; this version posted November 20, 2019. The copyright holder for this preprint (which was not certified by peer review) is the author/funder, who has granted bioRxiv a license to display the preprint in perpetuity. It is made available under aCC-BY-NC-ND 4.0 International license.

Landscape scenarios and implications for streamflow in New England

Table 1. Storylines for New England Landscape Futures in 2060. Scenario icons and descriptions are adapted with permission from Fallon Lambert et al. (2018).

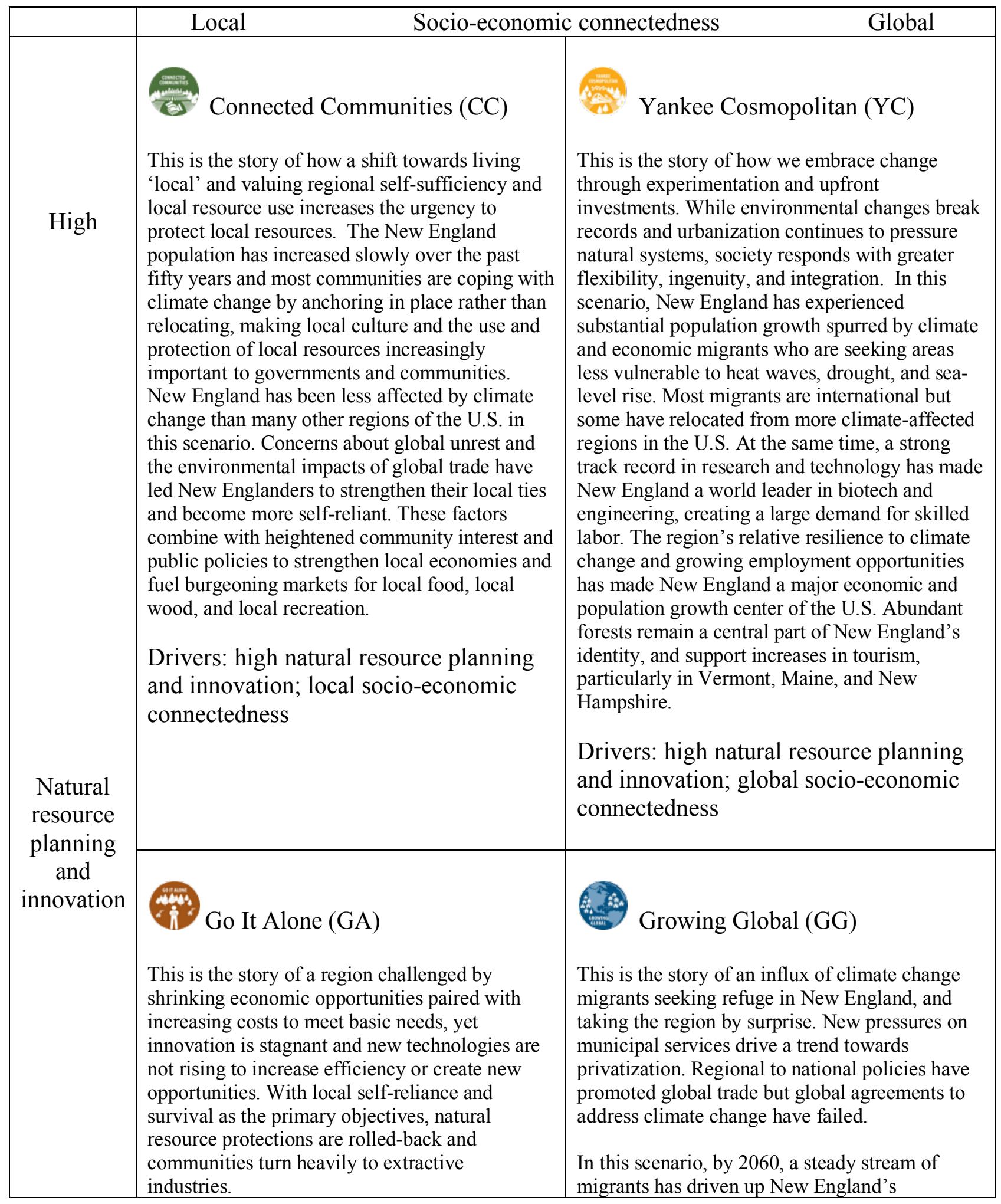


Landscape scenarios and implications for streamflow in New England

\begin{tabular}{|c|c|c|}
\hline Low & $\begin{array}{l}\text { In this scenario, population growth in the region } \\
\text { has remained fairly low and stable over the past } \\
50 \text { years as the lack of economic opportunity, } \\
\text { high energy costs, and tightened national borders } \\
\text { have deterred immigration and the relocation of } \\
\text { people from within the U.S. to New England. } \\
\text { The concurrent shrinking of national budgets and } \\
\text { lack of global economic connections have left } \\
\text { little leeway to deal with challenges such as high } \\
\text { unemployment, demographic change, and } \\
\text { climate resilience. Within New England this has } \\
\text { resulted in the rolling back of natural resource } \\
\text { protection policies and the drying up of } \\
\text { investments in new technologies and ecosystem } \\
\text { protections in response to a lack of regulatory } \\
\text { drivers. Over the last } 50 \text { years, the region has } \\
\text { seen the significant degradation of ecosystem } \\
\text { services as a result of poor planning, increased } \\
\text { pollution, and heavy extractive uses of local } \\
\text { resources using conventional technologies. } \\
\text { Drivers: low natural resource planning } \\
\text { and innovation; local socio-economic } \\
\text { connectedness }\end{array}$ & $\begin{array}{l}\text { population, with newcomers seeking to live in } \\
\text { areas with few natural hazards, ample clean air } \\
\text { and water, and low vulnerability to climate } \\
\text { change. This influx of people has taken the } \\
\text { region by surprise and local planning efforts have } \\
\text { failed to keep pace with development. The region } \\
\text { has experienced increasing privatization of } \\
\text { municipal services as state and local } \\
\text { governments struggle to keep up with the needs } \\
\text { of the burgeoning population. Trade barriers } \\
\text { were lifted in the 2020s to counter economic } \\
\text { stagnation and the volume of global trade has } \\
\text { multiplied over the past } 40 \text { years as a result of } \\
\text { increasing globalization. However, all attempts at } \\
\text { global climate change negotiations and } \\
\text { renewable energy commitments have failed in } \\
\text { this globally divided world. } \\
\text { Drivers: low natural resource planning } \\
\text { and innovation; global socio-economic } \\
\text { connectedness }\end{array}$ \\
\hline
\end{tabular}


bioRxiv preprint doi: https://doi.org/10.1101/847186; this version posted November 20, 2019. The copyright holder for this preprint (which was not certified by peer review) is the author/funder, who has granted bioRxiv a license to display the preprint in perpetuity. It is made available under aCC-BY-NC-ND 4.0 International license.

Landscape scenarios and implications for streamflow in New England

Table 2. Fractional land use across scenarios and watersheds.

\begin{tabular}{|l|l|c|c|c|}
\hline Watershed & $\begin{array}{l}\text { Land-use } \\
\text { scenario }\end{array}$ & $\circ$ Urban & $\circ$ Forest & \% Agriculture \\
\hline \multirow{5}{*}{ Cocheco } & 2010 & 14.3 & 75.5 & 4.4 \\
\cline { 2 - 5 } & RT & 22.8 & 66.7 & 4.7 \\
\cline { 2 - 5 } & GA & 16.1 & 73.8 & 4.3 \\
\cline { 2 - 5 } & GC & 14.6 & 74.3 & 5.3 \\
\cline { 2 - 5 } & YC & 39.6 & 49.9 & 4.7 \\
\cline { 2 - 5 } & GG & 65.7 & 18.6 & 9.8 \\
\hline \multirow{5}{*}{ Charles } & 2010 & 35.2 & 50.6 & 6.2 \\
\cline { 2 - 5 } & RT & 50.7 & 35.2 & 6.1 \\
\cline { 2 - 5 } & GA & 47.7 & 38.4 & 5.8 \\
\cline { 2 - 5 } & GC & 41.8 & 43.3 & 6.9 \\
\cline { 2 - 5 } & YC & 63.8 & 22.8 & 6.8 \\
\cline { 2 - 5 } & GG & 68.9 & 16.2 & \\
\hline
\end{tabular}


Table 3. Calibrated parameters for SWAT models of the Cocheco River and Charles River watersheds.

\begin{tabular}{|c|c|c|c|}
\hline Description & SWAT file & Cocheco & Charles \\
\hline Soil evaporation compensation factor &. $\mathrm{bsn}$ & 0.84 & 0.99 \\
\hline Surface runoff lag coefficient & .bsn & 3.94 & 4.62 \\
\hline $\begin{array}{l}\text { Fraction of transmission loss from } \\
\text { main channel that enter deep aquifer }\end{array}$ &.$b s n$ & 0.01 & 0.01 \\
\hline Plant uptake compensation factor & .bsn & 0.69 & 0.95 \\
\hline Baseflow alpha factor (1/days) &. $\mathrm{gW}$ & 0.19 & 0.22 \\
\hline Groundwater delay time (days) & gw & 32.16 & 36.37 \\
\hline $\begin{array}{l}\text { Threshold depth in the shallow aquifer } \\
\text { required for return flow (mm H20) }\end{array}$ &.$g w$ & 972.19 & 1150.78 \\
\hline Groundwater "revap" coefficient &. $\mathrm{gW}$ & 0.06 & 0.08 \\
\hline Deep aquifer percolation fraction &. $\mathrm{gW}$ & 0.09 & 0.08 \\
\hline $\begin{array}{l}\text { Threshold depth in the shallow aquifer } \\
\text { for "revap" or percolation to the deep } \\
\text { aquifer (mm H2O) }\end{array}$ &.$g w$ & 1027.11 & 534.91 \\
\hline $\begin{array}{l}\text { Soil evaporation compensation factor } \\
\text { for HRUs }\end{array}$ & hru & 0.98 & 1.00 \\
\hline Plant uptake compensation factor & .hru & 0.78 & 0.09 \\
\hline $\begin{array}{l}\text { Baseflow alpha factor for bank storage } \\
\text { (days) }\end{array}$ & .rte & 0.81 & 0.70 \\
\hline $\begin{array}{l}\text { Effective hydraulic conductivity in } \\
\text { main channel alluvium }(\mathrm{mm} / \mathrm{hr})\end{array}$ & .rte & 242.34 & 405.11 \\
\hline $\begin{array}{l}\text { Available water content of the soil } \\
(\mathrm{mm} \mathrm{H} 2 \mathrm{O} / \mathrm{mm} \text { soil) for hydric class A }\end{array}$ & .sol & 0.22 & 0.20 \\
\hline $\begin{array}{l}\text { Available water content of the soil } \\
\text { (mm H2O/mm soil) for hydric class B }\end{array}$ & .sol & 0.30 & 0.30 \\
\hline $\begin{array}{l}\text { Available water content of the soil } \\
(\mathrm{mm} \mathrm{H} 2 \mathrm{O} / \mathrm{mm} \text { soil) for hydric class } \mathrm{C}\end{array}$ & .sol & 0.19 & 0.08 \\
\hline $\begin{array}{l}\text { Available water content of the soil } \\
\text { (mm H2O/mm soil) for hydric class D }\end{array}$ & .sol & 0.15 & 0.16 \\
\hline $\begin{array}{l}\text { Saturated hydraulic conductivity } \\
(\mathrm{mm} / \mathrm{hr}) \text { for hydric class A }\end{array}$ & .sol & 236.58 & 65.47 \\
\hline $\begin{array}{l}\text { Saturated hydraulic conductivity } \\
(\mathrm{mm} / \mathrm{hr}) \text { for hydric class B }\end{array}$ & .sol & 391.94 & 492.62 \\
\hline $\begin{array}{l}\text { Saturated hydraulic conductivity } \\
(\mathrm{mm} / \mathrm{hr}) \text { for hydric class } \mathrm{C}\end{array}$ & .sol & 259.36 & 252.56 \\
\hline $\begin{array}{l}\text { Saturated hydraulic conductivity } \\
(\mathrm{mm} / \mathrm{hr}) \text { for hydric class D }\end{array}$ & .sol & 321.95 & 343.35 \\
\hline $\begin{array}{l}\text { Effective hydraulic conductivity in } \\
\text { tributary channel alluvium ( } \mathrm{mm} / \mathrm{hr})\end{array}$ &. sub & 170.37 & 330.13 \\
\hline
\end{tabular}


bioRxiv preprint doi: https://doi.org/10.1101/847186; this version posted November 20, 2019. The copyright holder for this preprint (which was not certified by peer review) is the author/funder, who has granted bioRxiv a license to display the preprint in perpetuity. It is made available under aCC-BY-NC-ND 4.0 International license.

Landscape scenarios and implications for streamflow in New England

Table 4. Goodness-of-fit for SWAT models of the Charles River and Cocheco River watersheds. NSE is the Nash-Sutcliffe efficiency, and RSR is the ratio of the root-mean-squared error to the standard deviation of the observations. All goodness-of-fit statistics were calculated in R with the hydroGOF package (Zambrano-Bigiarini, 2017).

\begin{tabular}{|l|l|l|c|c|c|}
\hline Watershed & Description & Years & NSE & Bias & RSR \\
\hline \multirow{3}{*}{ Cocheco } & calibration & $2002-2011$ & 0.58 & $-13.6 \%$ & 0.64 \\
\cline { 2 - 6 } & validation & $2012-2017$ & 0.49 & $-19.5 \%$ & 0.72 \\
\cline { 2 - 6 } & overall & $2002-2017$ & 0.58 & $-15.3 \%$ & 0.65 \\
\hline \multirow{3}{*}{ Charles } & calibration & $2002-2011$ & 0.74 & $1.2 \%$ & 0.51 \\
\cline { 2 - 6 } & validation & $2012-2017$ & 0.74 & $23.3 \%$ & 0.51 \\
\cline { 2 - 6 } & overall & $2002-2017$ & 0.75 & $7.2 \%$ & 0.5 \\
\hline
\end{tabular}


bioRxiv preprint doi: https://doi.org/10.1101/847186; this version posted November 20, 2019. The copyright holder for this preprint (which was not certified by peer review) is the author/funder, who has granted bioRxiv a license to display the preprint in perpetuity. It is made available under aCC-BY-NC-ND 4.0 International license.

Landscape scenarios and implications for streamflow in New England

Table 5. Average annual fluxes across simulations. HW and FC indicate simulations under historic weather and a future climate, respectively. Scenarios are denoted as follows: $2010-$ historic land use in 2010, RT - Recent Trends, GA - Go It Alone, CC - Connected Communities, YC - Yankee Cosmopolitan, GG - Growing Global.

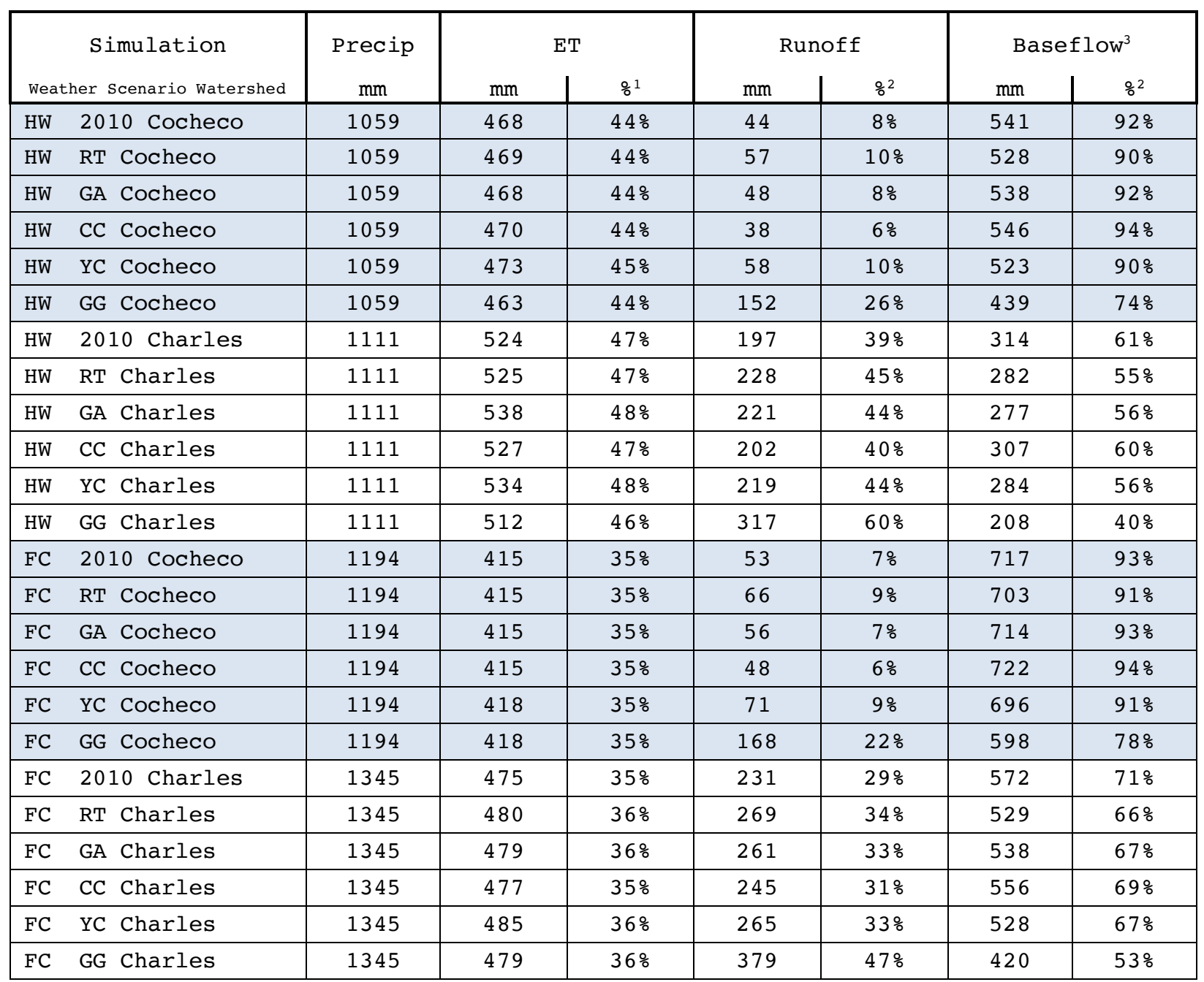

${ }^{1}$ percentage of precipitation. ${ }^{2}$ percentage of total streamflow

${ }^{3}$ Baseflow calculated as Water Yield - Storm Runoff 
bioRxiv preprint doi: https://doi.org/10.1101/847186; this version posted November 20, 2019. The copyright holder for this preprint (which was not certified by peer review) is the author/funder, who has granted bioRxiv a license to display the preprint in perpetuity. It is made available under aCC-BY-NC-ND 4.0 International license.

Landscape scenarios and implications for streamflow in New England

Table 6. Seasonal evapotranspiration (ET), storm runoff (SR), and baseflow (BF), in mm, for the Cocheco River watershed.

\begin{tabular}{|c|c|c|c|c|c|c|c|c|c|c|c|c|}
\hline & \multicolumn{6}{|c|}{ Historic Weather } & \multicolumn{6}{|c|}{ Future Climate } \\
\hline & \multicolumn{3}{|c|}{2010 Land Use } & \multicolumn{3}{|c|}{ Growing Global } & \multicolumn{3}{|c|}{2010 Land Use } & \multicolumn{3}{|c|}{ Growing Global } \\
\hline & $\mathrm{ET}$ & SR & $\mathrm{BF}$ & $\mathrm{ET}$ & SR & $\mathrm{BF}$ & $\mathrm{ET}$ & SR & $\mathrm{BF}$ & $\mathrm{ET}$ & SR & $\mathrm{BF}$ \\
\hline Fall & 93 & 11 & 126 & 92 & 41 & 105 & 84 & 11 & 155 & 82 & 36 & 125 \\
\hline Winter & 29 & 6 & 94 & 27 & 22 & 73 & 20 & 19 & 203 & 18 & 52 & 161 \\
\hline Spring & 129 & 19 & 196 & 122 & 56 & 155 & 118 & 18 & 247 & 112 & 60 & 209 \\
\hline Summer & 218 & 8 & 125 & 222 & 34 & 107 & 193 & 5 & 112 & 206 & 21 & 103 \\
\hline
\end{tabular}


bioRxiv preprint doi: https://doi.org/10.1101/847186; this version posted November 20, 2019. The copyright holder for this preprint (which was not certified by peer review) is the author/funder, who has granted bioRxiv a license to display the preprint in perpetuity. It is made available under aCC-BY-NC-ND 4.0 International license.

Landscape scenarios and implications for streamflow in New England

Table 7. Seasonal evapotranspiration (ET), storm runoff (SR), and baseflow (BF), in mm, for the Charles River watershed.

\begin{tabular}{|c|c|c|c|c|c|c|c|c|c|c|c|c|}
\hline & \multicolumn{6}{|c|}{ Historic Weather } & \multicolumn{6}{|c|}{ Future Climate } \\
\hline & \multicolumn{3}{|c|}{2010 Land Use } & \multicolumn{3}{|c|}{ Growing Global } & \multicolumn{3}{|c|}{2010 Land Use } & \multicolumn{3}{|c|}{ Growing Global } \\
\hline & $\mathrm{ET}$ & $\mathrm{SR}$ & $\mathrm{BF}$ & $\mathrm{ET}$ & SR & $\mathrm{BF}$ & $\mathrm{ET}$ & $\mathrm{SR}$ & $\mathrm{BF}$ & $\mathrm{ET}$ & SR & $\mathrm{BF}$ \\
\hline Fall & 113 & 42 & 42 & 115 & 70 & 25 & 94 & 59 & 115 & 96 & 95 & 76 \\
\hline Winter & 43 & 43 & 100 & 42 & 69 & 70 & 34 & 72 & 192 & 34 & 115 & 144 \\
\hline Spring & 129 & 66 & 121 & 124 & 102 & 84 & 130 & 60 & 186 & 128 & 99 & 145 \\
\hline Summer & 239 & 45 & 51 & 232 & 76 & 30 & 217 & 41 & 79 & 221 & 71 & 55 \\
\hline
\end{tabular}


bioRxiv preprint doi: https://doi.org/10.1101/847186; this version posted November 20, 2019. The copyright holder for this preprint (which was not certified by peer review) is the author/funder, who has granted bioRxiv a license to display the preprint in perpetuity. It is made available under aCC-BY-NC-ND 4.0 International license.

Landscape scenarios and implications for streamflow in New England

Table 8. High-density urban area (URHD), medium/low density urban area (URML), impervious area, and average annual maximum daily flows across the simulations. Scenarios are denoted as follows: 2010 - historic land use in 2010, RT - Recent Trends, GA - Go It Alone, CC Connected Communities, YC - Yankee Cosmopolitan, GG - Growing Global.

\begin{tabular}{|c|c|c|c|c|c|c|}
\hline Watershed & $\begin{array}{l}\text { Land Use } \\
\text { Scenario }\end{array}$ & \% URHD & \% URML & \% Impervious & $\begin{array}{c}\text { Historic } \\
\text { Weather } \\
\text { Average Max } \\
\text { Daily Flow, } \\
\text { cms }\end{array}$ & $\begin{array}{c}\text { Future } \\
\text { Climate } \\
\text { Average Max } \\
\text { Daily Flow, } \\
\text { cms }\end{array}$ \\
\hline \multirow{6}{*}{ Cocheco } & 2010 & 2.2 & 12.1 & 5.3 & 32.0 & 33.6 \\
\hline & $\mathrm{RT}$ & 2.5 & 20.3 & 7.8 & 32.7 & 34.0 \\
\hline & GA & 2.4 & 13.7 & 5.9 & 32.2 & 33.7 \\
\hline & $\mathrm{CC}$ & 2.9 & 11.7 & 5.8 & 32.1 & 33.7 \\
\hline & $\mathrm{YC}$ & 3.4 & 36.2 & 13.0 & 32.5 & 34.0 \\
\hline & GG & 14.6 & 51.1 & 27.0 & 34.7 & 37.3 \\
\hline \multirow{6}{*}{ Charles } & 2010 & 5.5 & 29.7 & 13.1 & 40.4 & 47.3 \\
\hline & $\mathrm{RT}$ & 7.5 & 43.2 & 18.5 & 41.8 & 48.5 \\
\hline & GA & 7.0 & 40.8 & 17.4 & 41.0 & 48.3 \\
\hline & $\mathrm{CC}$ & 11.0 & 30.8 & 18.3 & 41.4 & 48.5 \\
\hline & $\mathrm{YC}$ & 10.0 & 53.9 & 23.7 & 41.9 & 48.4 \\
\hline & GG & 24.4 & 44.5 & 34.0 & 44.2 & 52.3 \\
\hline
\end{tabular}


Landscape scenarios and implications for streamflow in New England

\section{Figure Captions}

Figure 1. Locations of the Cocheco River watershed and the Charles River watershed with land covers from 2010. [color]

Figure 2. Land use for the Cocheco River watershed. LU2010 indicates land use in 2010 from the NLCD. Recent Trends, Connected Communities, Yankee Cosmopolitan, Go It Alone, and Growing Global represent plausible land-use scenarios in 2060. [color]

Figure 3. Land use for the Charles River watershed. LU2010 indicates land use in 2010 from the NLCD. Recent Trends, Connected Communities, Yankee Cosmopolitan, Go It Alone, and Growing Global represent plausible land-use scenarios in 2060. [color]

Figure 4. Average water balances for the Charles River and Cocheco River watersheds across scenarios and climates.

Figure 5. Seasonal water yield for the Cocheco and Charles River watersheds under for land use from 2010 and historic weather (HW) and a future climate (FC). Seasons are represented by colors, from the bottom: orange - autumn (SON); gray - winter (DJF); blue - spring (MAM); green - summer (JJA). [color]

Figure 6. Difference in annual maximum daily flow (AMDF) between land-use scenarios and historic land use in 2010 for the Charles River watershed. Bars represent 95\%-confidence limits determined via bootstrap, and the line in the middle represents the mean difference in AMDF between that scenario and land use in 2010. Scenarios are denoted as follows: RT - Recent Trends, GA - Go It Alone, CC - Connected Communities, YC - Yankee Cosmopolitan, GG Growing Global.

Figure 7. Difference in annual maximum daily flow (AMDF) between land-use scenarios and historic land use in 2010 for the Cocheco River watershed. Bars represent 95\%-confidence limits determined via bootstrap, and the line in the middle represents the mean difference in AMDF between that scenario and land use in 2010. Scenarios are denoted as follows: RT Recent Trends, GA - Go It Alone, CC - Connected Communities, YC - Yankee Cosmopolitan, GG - Growing Global.

Figure 8. Average annual maximum daily flow increases with impervious area. Land-use scenarios are indicated by letter codes: 2010 - historic land use in 2010, RT - Recent Trends, GA - Go It Alone, CC - Connected Communities, YC - Yankee Cosmopolitan, GG - Growing Global. Bold indicates simulations for a future climate and normal font represents historic weather. The larger font (and higher magnitude flows) are for the Charles River watershed, and the smaller font is for the Cocheco River watershed. For the Charles River watershed, results for Go It Alone, Connected Communities, and Recent Trends are very similar and plot on top of each other. For the Cocheco River watershed, results for Go It Alone, Connected Communities, and land use in 2010 are very similar and plot on top of each other. 
bioRxiv preprint doi: https://doi.org/10.1101/847186; this version posted November 20,2019 . The copyright holder for this preprint (which was not certified by peer review) is the author/funder, who has granted bioRxiv a license to display the preprint in perpetuity. It is made available under aCC-BY-NC-ND 4.0 International license.

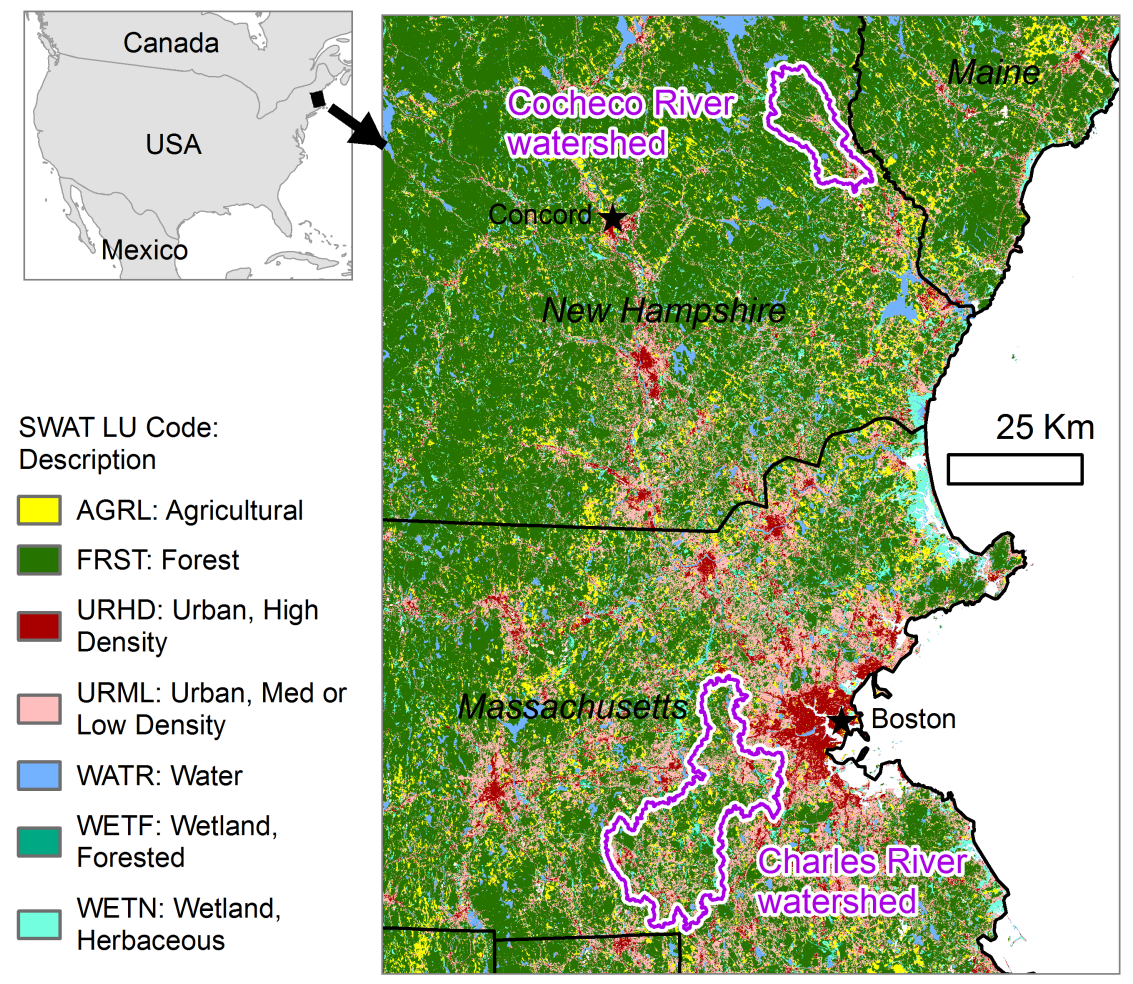


bioRxiv preprint doi: https://doi.org/10.1101/847186; this version posted November 20, 2019. The copyright holder for this preprint (which was
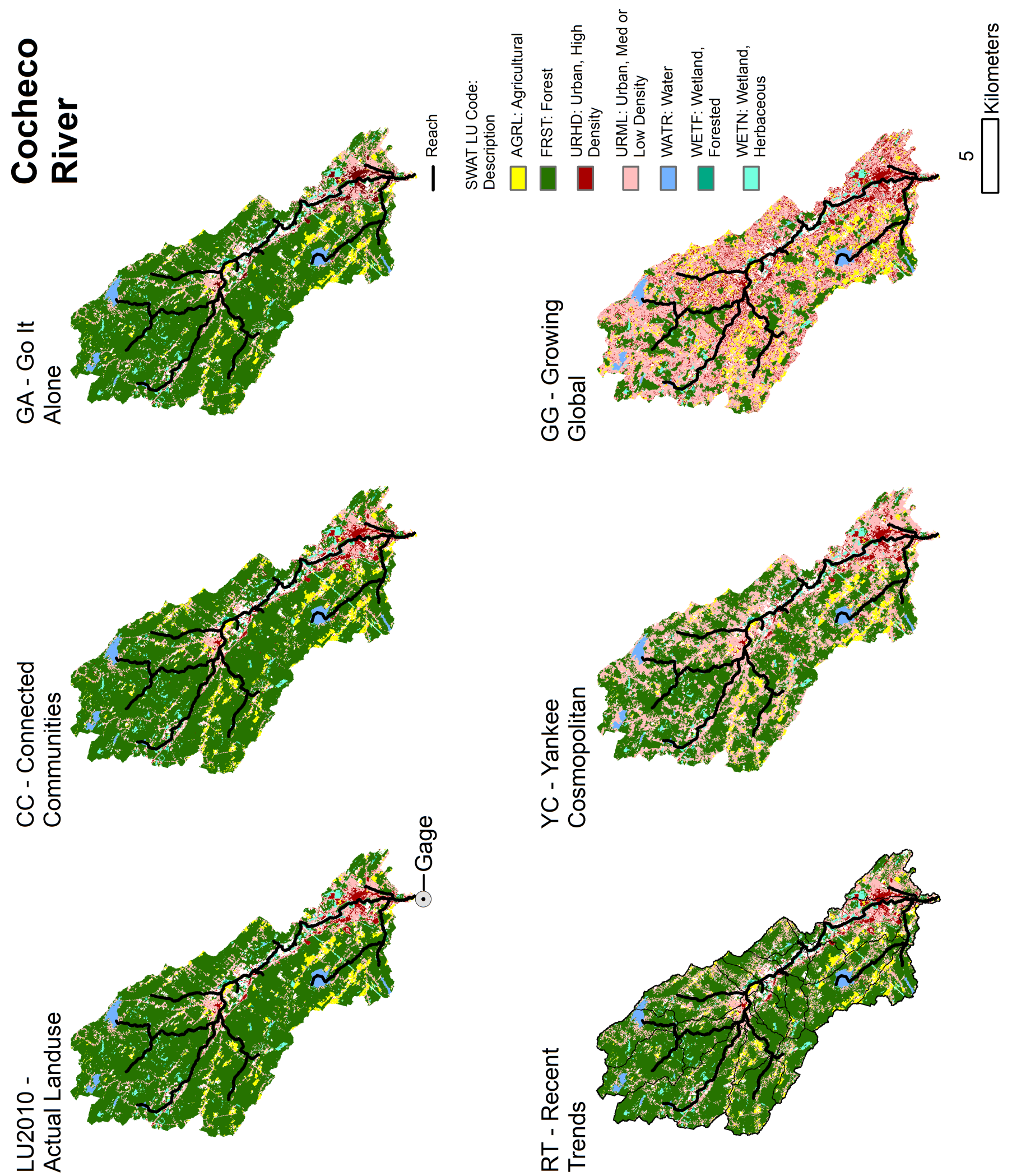
bioRxiv preprint doi: https://doi.org/10.1101/847186; this version posted November 20, 2019. The copyright holder for this preprint (which was
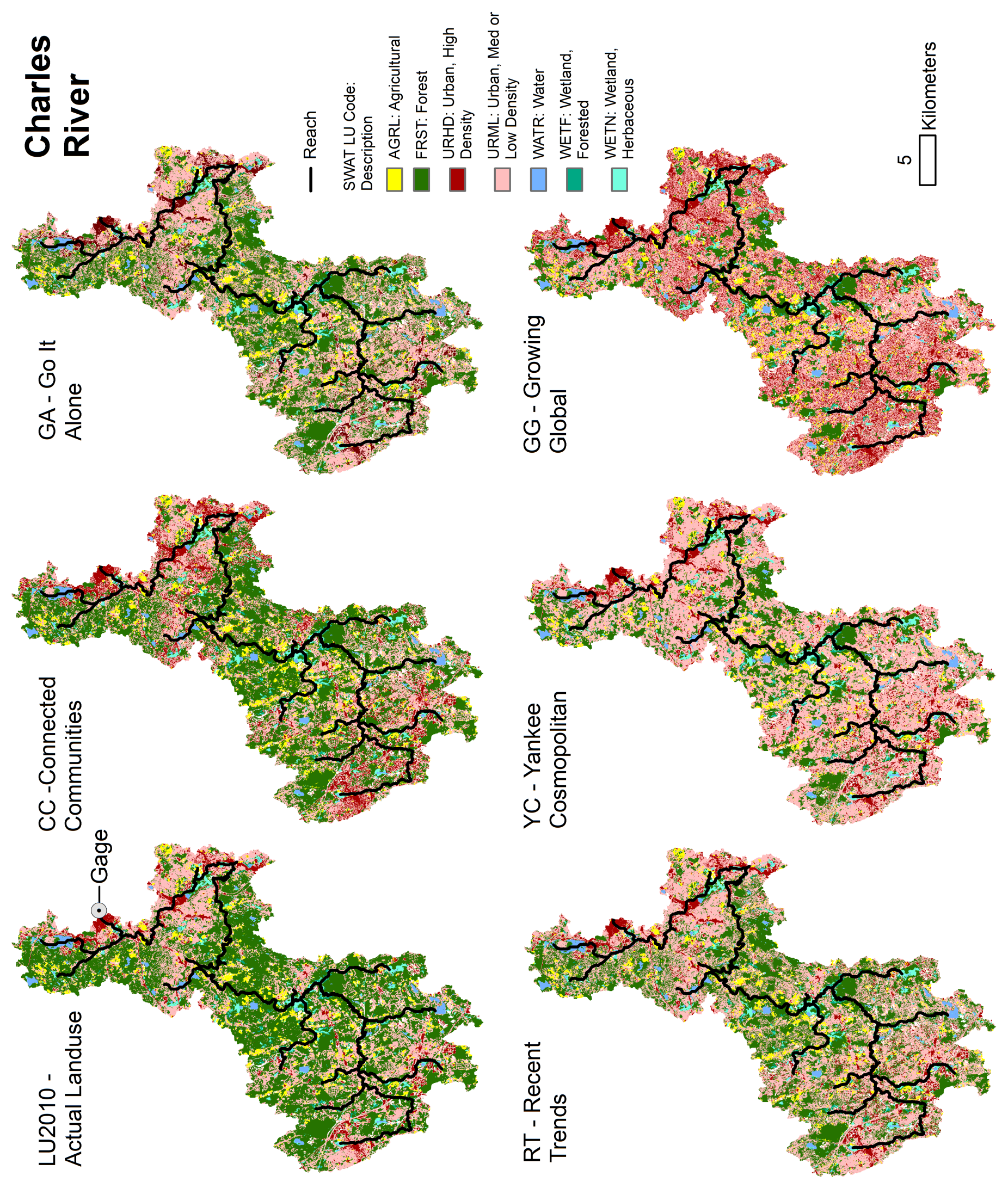


\section{Charles River}

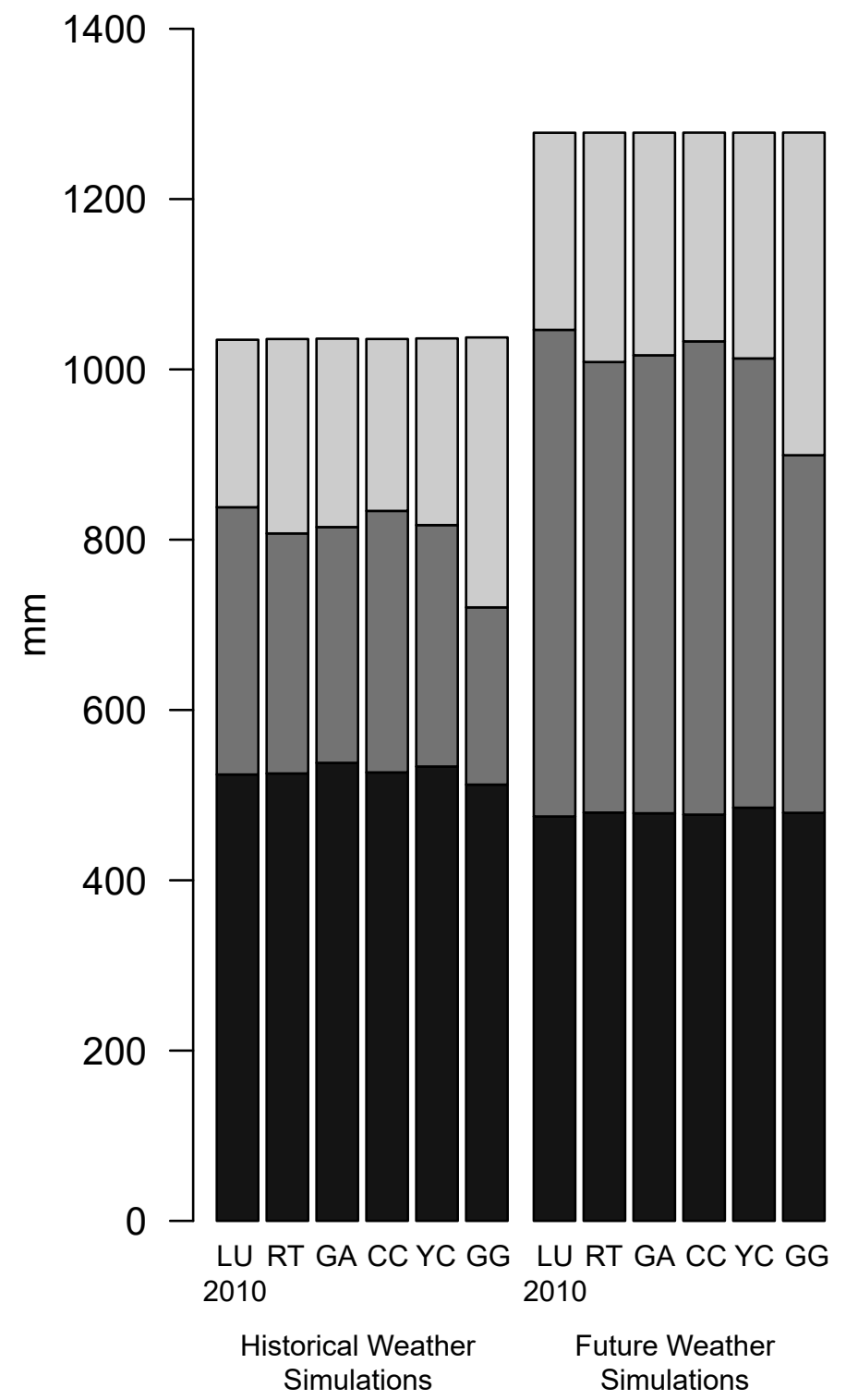

Cocheco River

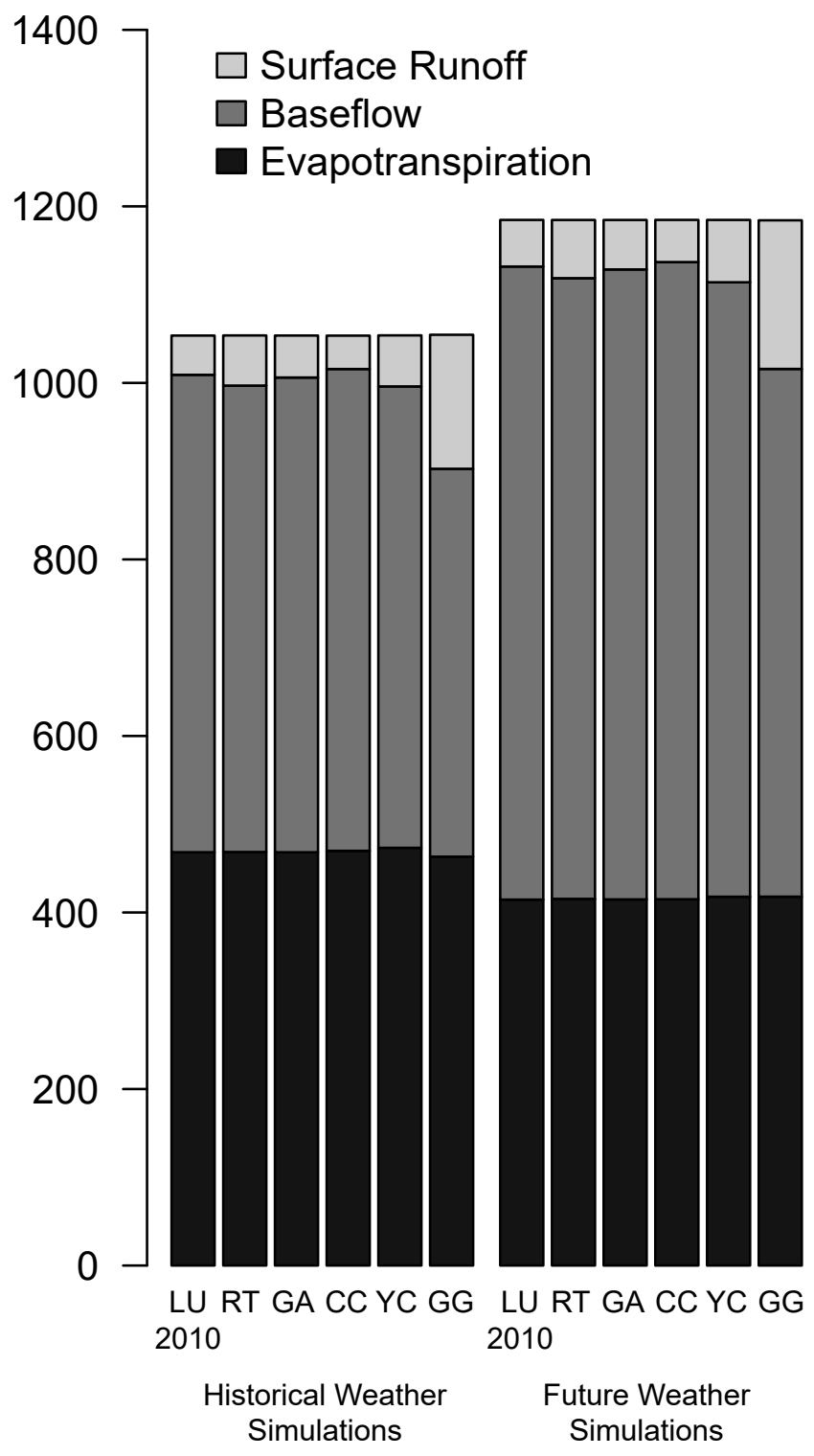


bioRxiv preprint doi: https://doi.org/10.1101/847186; this version posted November 20, 2019. The copyright holder for this preprint (which was not certified by peer review) is the author/funder, who has granted bioRxiv a license to display the preprint in perpetuity. It is made available under aCC-BY-NC-ND 4.0 International license.

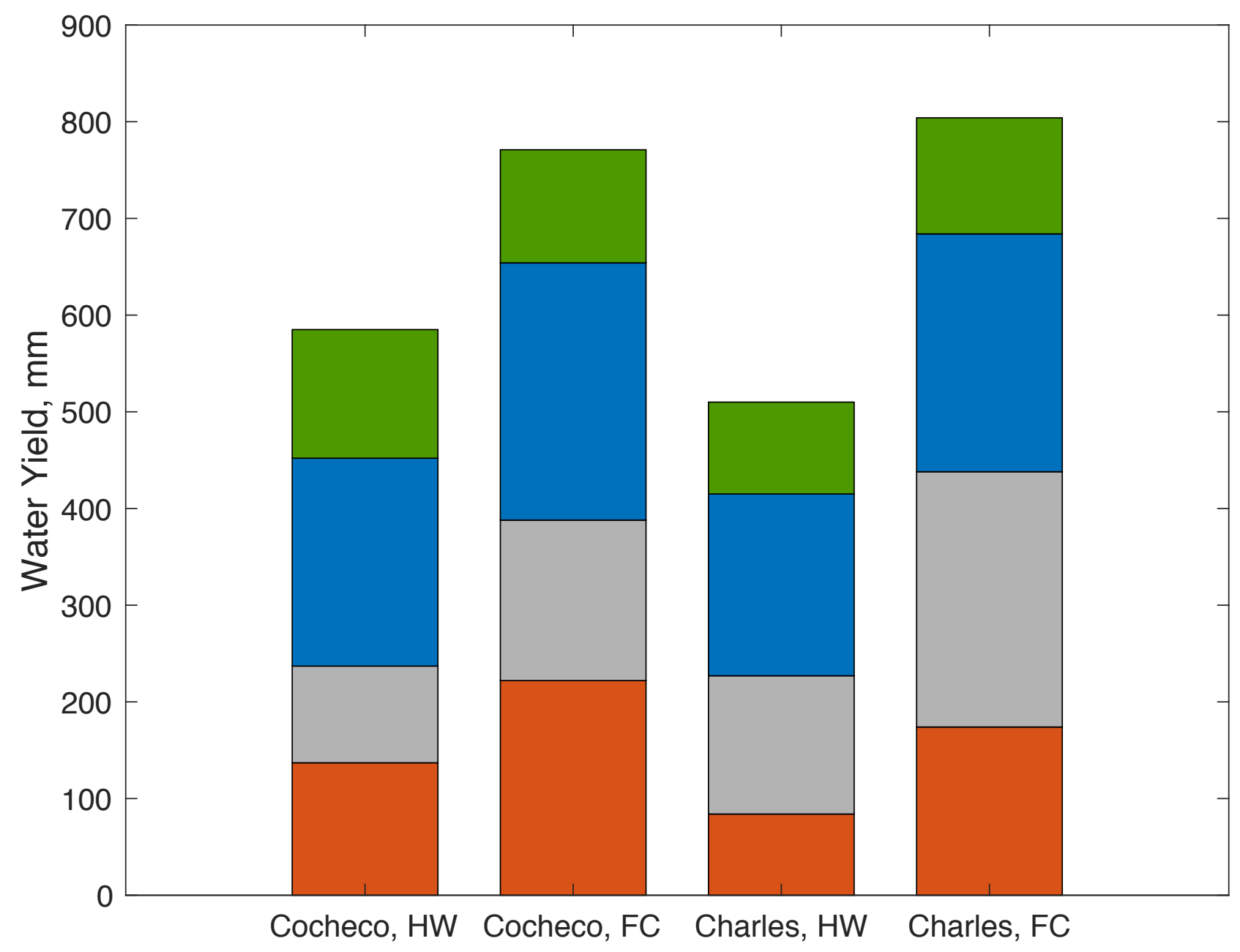




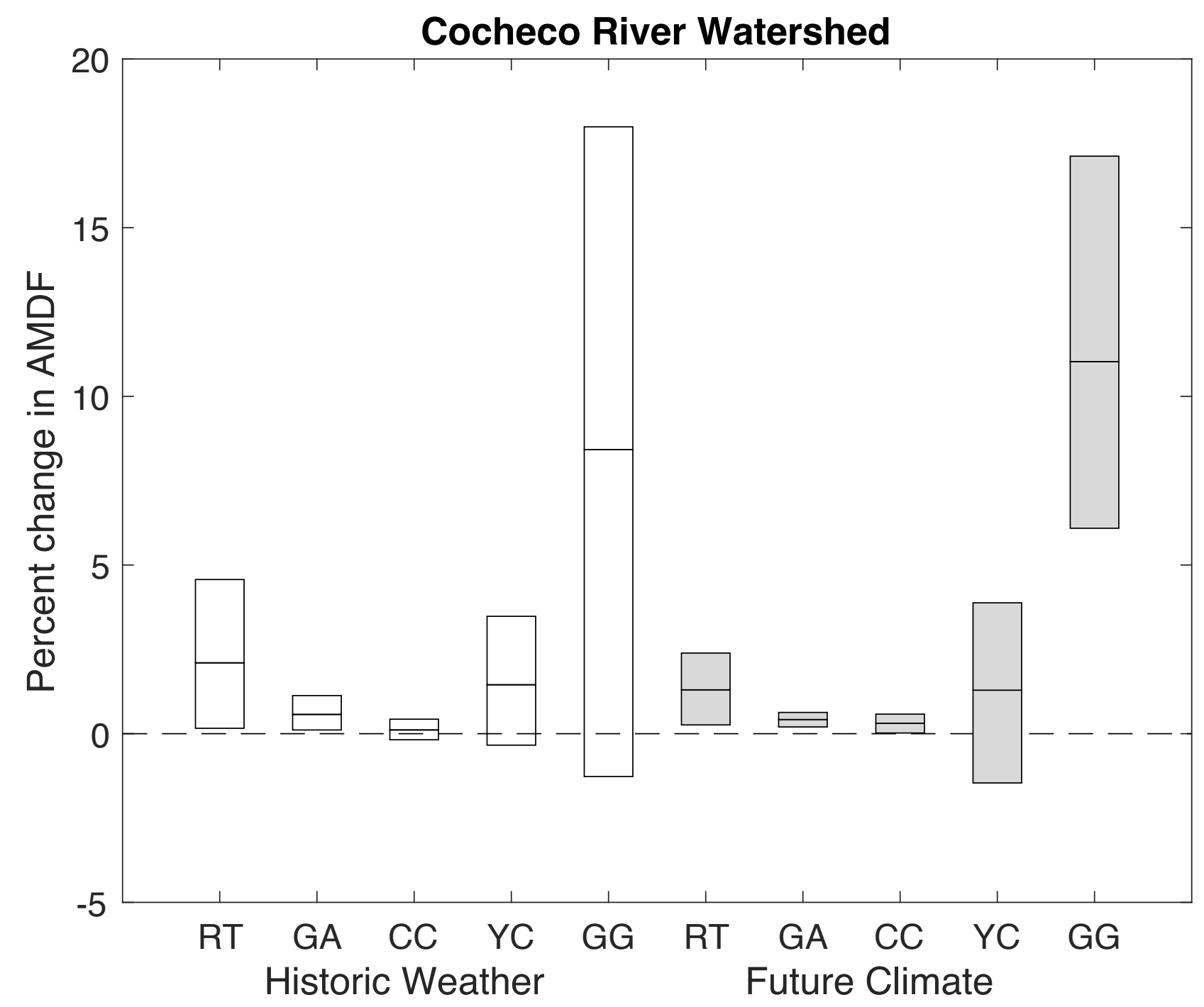




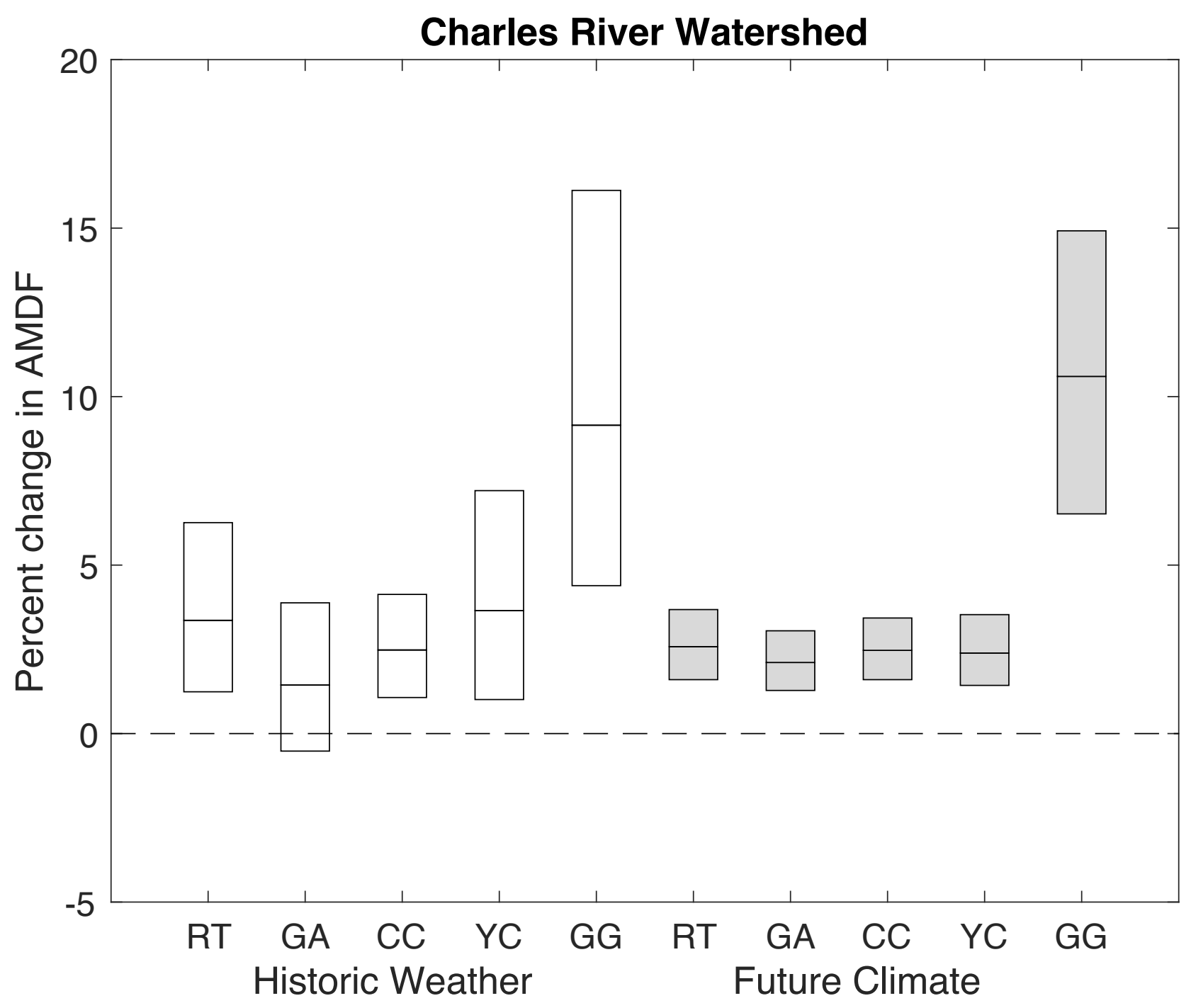




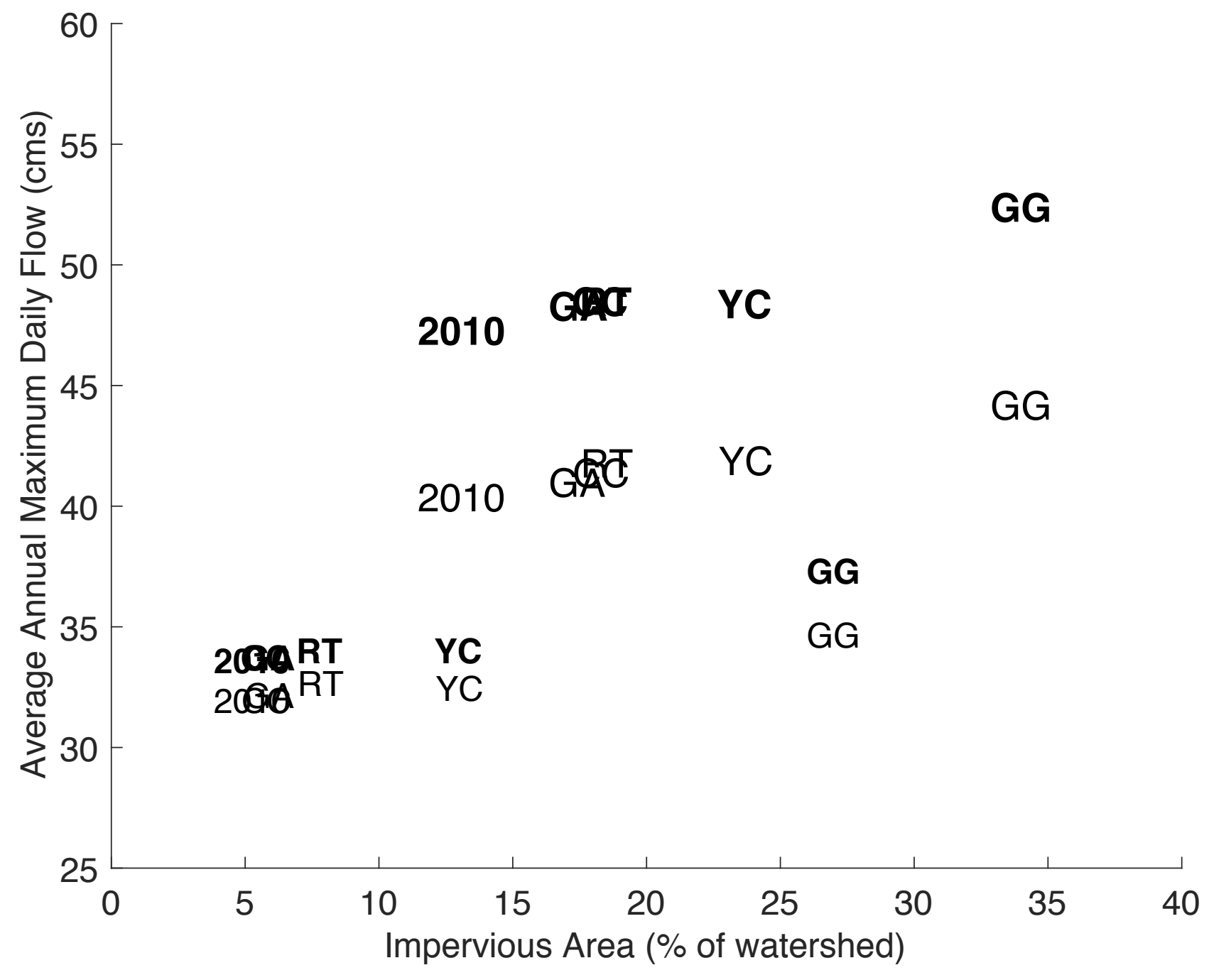

